Hageman, S.J., Lukasik, J., McGowran, B. and Bone, Y. 2003. Paleoenvironmental significance of Celleporaria (Bryozoa) from modern and Tertiary cool-water carbonates of southern Australia. Palaios, 18 (6): :510-527. Published by Society for Sedimentary Geology (SEPM) (ISSN: 0883-1351) The version of record is available at http://palaios.geoscienceworld.org/ [Archived with permission of the editor received Feb 22, 2011]

\title{
Paleoenvironmental Significance of Celleporaria (Bryozoa) from Modern and Tertiary Cool-water Carbonates of Southern Australia
}

\section{Steven J. Hageman, Jeff Lukasik, Brian Mcgowran, and Yvonne Bone}

\begin{abstract}
Certain members of the bryozoan genus Celleporaria form large, erect colonies of hollow branches ( $\sim 10-30 \mathrm{~cm}$ tall and 1-3 cm diameter). These are common and conspicuous in Pleistocene and Cenozoic neritic strata of the southern margin of Australia. Most of these basins are characterized by decimeter-scale cycles through subtidal, heterozoan, cool-water, carbonate sediments. Several intervals are further characterized by pervasive celleporarid bryozoan thickets (10-30 cm thick), individual units of which can be traced for many tens of kilometers.
\end{abstract}

Study of modern, live celleporarid bryozoans from the continental shelf of the Great Australian Bight (GAB), Pleistocene celleporarid mounds stranded below the shelf break of the Australian margin, and Miocene celleporarid thickets from the Murray and Torquay Basins indicates that Celleporaria thickets form under specific environmental conditions: i.e., low-energy or sub-swell wave-base settings, mud-silt substrate, medium-high mesotrophy, and moderate sedimentation rate. These conditions, however, are not site specific. They are manifested here in two different environmental settings: (1) a deep-water ( $>200 \mathrm{~m})$, upwelling nutrient source, below the shelf break during extreme sea-level low stands; and (2) shallow-water $(<50 \mathrm{~m})$, terrestrial nutrient source, in embayments, far inland from the shelf break during relative high stands of sea-level.

The celleporarid growth habit (species specific—not an ecomorph) allows their populations to proliferate in spatially restricted, transitional, geologically short-lived environments where most other bryozoans cannot cope. Their environmental sensitivity means that Celleporaria have great potential for paleoenvironmental analysis of Cenozoic carbonate Tethyan sediments. 


\section{ARTICLE}

\section{INTRODUCTION}

Large colonies of the Bryozoa Celleporaria (commonly misidentified as Cellepora) are characteristic and distinguishing components of many Tertiary limestones distributed along the southern margin of Australia (Fig. 1). These large, multilaminate, hollow-cylindrical bryozoans, with branches reaching $3 \mathrm{~cm}$ in diameter (Figs. 2, 3), commonly form thickets or biostromes up to $30 \mathrm{~cm}$ in height. Despite their characteristic morphology, abundance, and routine documentation in the field, the paleoecology and paleoenvironmental significance of Celleporaria are not well understood. Discovery of living and non-living colonies of Celleporaria with this distinctive growth habit found off the southwestern Australian shelf (Fig. 1, label "I") provides insight into their modern ecology, and helps to evaluate the paleoenvironmental significance of those within the onshore Tertiary limestones. These findings also may have significance for the Cenozoic Tethyan forms found in southern Europe and northern Africa (Spjeldnaes and Moissette, 1997).

The primary goal of this paper lies in identifying the environmental parameters that control the distribution of the large, multilaminate, hollow-cylindrical Celleporaria. This paper documents (1) growth habit characteristics of Celleporaria, (2) distribution of Celleporaria in modern shelf environments, (3) distribution of Miocene Celleporaria-rich limestones in the Murray and Torquay basins of southeastern Australia, and (4) the significance of Celleporaria with respect to specific environmental parameters governing their distribution.

\section{CELLEPORARIA (LEPRALIELLIDAE, CHEILOSTOMATA)}

\section{Taxonomy}

Celleporaria is a common and diverse genus with a global distribution of over 120 fossil and living described species. Species of Celleporaria, as a whole, exhibit many different colonial growth forms and have broad ecological preferences and tolerances. The traditional growthform descriptor "celliporiform" (Canu and Bassler, 1920) refers to their massive, multilaminate, pustulose nature, and encompasses a variety of colony shapes ranging from encrusting, to massive, nodular, and erect branching (the "nodular-arborescent" form of Bone and James, 1993). The morphological plasticity and complexity of ontogenetic variation among celleporarid 
zooids make their taxonomy challenging. Detailed taxonomic study is not, however, a goal of this paper (see Appendix).

This paper is concerned with a limited group of erect, multilaminate, hollow-branching celleporarids (Fig. 2) with the following growth habit characteristics (nomenclature of Hageman et al., 1998): an erect, rigid contiguous colony, originally cemented to a fistulose sponge substrate (mature colonies may resume upright growth after having been toppled or partially degenerated). Branches are thick (macroserial), but undifferentiated (nonmaculate, without specialized regions on the colony for excurrent feeding chimneys). Branches consist of multiple layers of zooids (multilaminate) formed by an irregular, pustulose arrangement of zooids growing directly on top of each other (frontal-budding). Branches are cylindrical, but hollow, as a result of growth around an ephemeral organic substrate. Branch segments are straight, with frequent bifurcations in more than one plane. Branches anastamose and fuse, forming a threedimensional box-work in mature colonies (Fig. 3A, 3D); however, branches never bud laterally, but are always continuous with a hollow growing edge. Structural support is achieved by the stacking of thin-walled zooecia, instead of by the more common process within various bryozoan taxa of secreting a thickened extra-zooidal skeleton. The modern taxa relevant to this paper are illustrated in Fig. 4, and briefly described in the Appendix.

Within this paper, as a matter of convenience, the name Celleporaria refers only to the closely related species group (e.g., Celleporaria oculata, C. fusca, C. gambierensis, and a number of undescribed species) that exhibits a specific erect, hollow-branching growth habit. Most Australian fossil specimens of this group are designated as Celleporaria gambierensis, although there are clear differences among Eocene, Oligo-Miocene, and Quaternary forms. These specimens are similar to, but different than C. palmata, which forms thickets in the Pliocene of the Mediterranean (Spjeldnaes and Moissette, 1997).

\section{Frontal Budding}

Most cheilostomatid bryozoans grow new zooids only along a proximal perimeter of the colony (growing edge or front). However, several groups of bryozoans have developed the ability to form new individuals by budding them from the surface of the colony. This evolutionary breakthrough (derived independently in several clades) allows colonies to grow in a fundamentally different manner than their ancestors (Banta, 1972; Rider and Cowen, 1977; Lidgard and Jackson, 1989). Celleporaria is even more specialized because its frontally budded zooids do not originate from a single parent zooid (Lidgard, 1985). This results in a rather haphazard, pustulose arrangement of actively feeding zooids at multiple levels (newly budded and partially overgrown) at the surface (Fig. 4). Frontal budding allows for rapid occupation of 
three-dimensional space. The thin zooecial walls, which display minimal secondary thickening, combined with the pustulose growth (Fig. 2B-C) result in a volumetrically large, structurally competent, colony form with a minimal investment in skeletal resources.

Celleporarid colonies grow by frontal budding and overgrowth of otherwise viable zooids on their surface. Instead of producing several generations of polypides in an individual zooecium before abandoning the zooecium, Celleporaria occupy more space with their available resources. Although antecedent layers of zooids lose contact with their exterior environment when they are overgrown, communication pores connect them with the rest of the colony (Lidgard, 1985). This pathway (funiculus) allows for nutrient regression during periods of environmental stress (Cummings, 1975).

Thus, specialized budding and growth have allowed species of Celleporaria to grow into some of the largest bryozoan colonies ever reported. For example, on jetty piles in the Gulf of St. Vincent and Spencer Gulf of South Australia, modern Celleporaria grow into heads up to one meter in diameter (12 years of observed growth from clean piles; Gowlett-Holmes, pers. comm.. 2002), similar to modern bryozoan reefs described from New Zealand (Bradstock and Gordon, 1983). They also grow as $20-50 \mathrm{~cm}$ diameter caps and domes in the Oligo-Miocene limestones from the Murray Basin, South Australia.

\section{Colony Growth Habit}

Celleporaria grow in three-dimensional anastomosing box-works (Fig. 3A, 3D). This is an uncommon growth habit for bryozoans, but also is observed in some modern forms such as erect schizoporellids (Chenal du Teychan, Bassin d'Archechon, France, $\sim 8 \mathrm{~m}$ water depth), Parasmittina fistulata from Western Australia (8 km SSE of Cape Bellefin from within 3-m-deep sandy bottom channels with Posidonia and Laurencia), and Parasmittina solenasmiliodes and Thalamoporella novaehollandiae from Cox's Peninsula near Palmerston, Northern Territory, Australia. All of these sites are in relatively protected settings.

This three-dimensional anastomosing box-work growth allows for colonies to escape from their primary substrate, with subsequent generations structurally supported above the substrate by earlier ones (i.e., self-supporting framework). This allows for growth in a setting surrounded by fine, unconsolidated sediment with continuous accumulation. An interpretation of an environment with significant sediment supply is also supported for Celleporaria by the abundance of unusually large and abundant spatulate avicularia (Fig. 4B-D), which are believed to be used to clean fine sediment from the colony surface (Rider and Cowen, 1977). Presence of large spatulate avicularia appears to be an inducible characteristic, because otherwise apparently conspecific colonies may or may not display large avicularia on their surface, 
suggesting presence or absence at different times during a single colony's developmental history.

\section{CELLEPORARIA FROM THE SOUTHERN AUSTRALIAN MARGIN (QUATERNARY)}

\section{Materials and Methods}

The distribution of Quaternary (living and relict) erect branching Celleporaria was investigated from the southern Australian continental shelf (Fig. 1, label "I"). Sea-floor samples were collected using an epibenthic sled (15 cm gape). Live material was sorted on ship, with representative collections preserved in $70 \% \mathrm{EtOH}$. Bulk sediment samples were washed and sieved in the laboratory. Every celleporarid specimen (living or dead) was removed and closely examined for each of the 139 bulk sediment samples from the Great Australian Bight (GAB) (Figs. 1 and 5). A less-detailed survey was made of celleporarids from all 218 bulk sediment samples from the Lincoln and Lacepede Shelves (Fig. 1, label "II"). The volume of original bulk sediment samples was not standardized, but was sufficient to characterize presence/absence of Celleporaria at each sample station ( 0 to $\sim 40$ specimens per sample).

\section{Geographic and Environmental Distribution within Region I: The Great Australian Bight and Southwestern Australia}

A survey of zooecial characteristics for all celleporarid bryozoan specimens regardless of growth habit (e.g., encrusting, massive, and erect) from the GAB sample sites (Figs. 1 and 5), suggests that the hollow-erect, branching growth habit is taxonomically determinate (i.e., a colony form generated by a species that does not grow in any other growth habit). That is, these unusual growth habits are not the result of some common bryozoan that exhibits widespread ecophenotypic plasticity. Only certain species of Celleporaria (differentiated by zooecial characteristics) were restricted to a hollow-erect, branching growth-form similar to those of the southern Australian Tertiary basins. Unlike most of the other dozen or so celleporarid species present in the GAB study area, these specific taxa were never found as encrusting, or as poorly developed solid erect branching growth forms. All of these specimens from the GAB (living, dead, relict) were found in varying abundance as isolated, non-fused colonies, suggesting that they were not growing in thickets or mounds on the shelf.

Live, hollow-erect branching Celleporaria colonies (fragments $7-10 \mathrm{~cm}$ ) were recovered from seven sample sites (Figs. 5 and 6). Each of the seven Celleporaria colonies was found growing on single digits of Oceanapia sp._-a living, pink, fistulose sponge (Fig. 2A). In some cases, the 
sponge extended beyond the branch of the mature celleporarid. In other cases, the bryozoan had outgrown the sponge, but retained a hollow central cavity for structural stability. Similar growth habits have been described for recent Mediterranean celleporarids on sponges, gorgonians, and serpulid worm tubes (Pouyet, 1973; Moissette and Pouyet, 1991).

Most of these live colonies were sampled between a water depth of 140 to $160 \mathrm{~m}$ (Figs. 5A and 6 ), although several were recovered from shallower sites (GAB-130 and GAB-135) at $\sim 100 \mathrm{~m}$. These depths are near but below the level of local swell wave base $(\sim 130 \mathrm{~m})$. The swell wave base is the water depth below which a hydrodynamic condition exists where sediment is not regularly reworked by waves (swells) generated by distant storms on the open ocean (James et al., 1992; James et al., 1997). No live colonies were recovered from the shallow, wave-swept, inner to middle shelf.

Non-living hollow-erect branching Celleporaria colonies were recovered from 16 localities (Figs. 5-6). It is difficult to determine the absolute age of non-living bryozoan skeletons on this shelf based on appearance alone. In general however, relict specimens (long dead or exhumed) are identified as those that are highly abraded, encrusted, and stained (usually gray rather than the brown staining of shoreward samples). Relict specimens were collected from outer-shelf to upper-slope environments in depths ranging from $\sim 180$ to 350 meters. Dead, but apparently not relict, colonies are locally abundant and have a similar to slightly shallower depth distribution to those of the living colonies ( $\sim 90-170 \mathrm{~m}$; Figs. 5A and 6).

\section{Geographic and Environmental Distribution within Region II: Shelf Edge of Central Southern Australia}

Comprehensive examination of Celleporaria specimens was not possible throughout the Otway, Bonney, Lacepede, and Lincoln Shelves due to sample availability, but relevant information can be obtained from published summaries of sediment distributions (James et al., 1992; Boreen et al, 1993; James et al., 1997, 2001). The distribution of hollow, cylindrical Celleporaria on the shelf in these regions is similar to that described here for the GAB, except for the thickets (mounds?) of Celleporaria described off of the shelf edge at $\approx 250-450$ m (James et al., 1992; Boreen et al., 1993; James et al., 1997). Specimens from these thickets yielded Late Pleistocene ages (13,760 to 21,210 ybp) through $\mathrm{C}^{14}$ dating (James et al., 1992; Bone and James, 1993; Boreen et al., 1993; James et al., 1997). These correspond to "Facies CC-CoralCelleporaria Facies" of James et al. (2001, fig. 10) from the GAB; "Facies 5: Shelf edge bryocoral biostrome" of James et al. (1997) of the Lincoln Shelf; and parts of "Facies 4A and 9: Robust bryozoan muddy sand" of James et al. (1992) and Boreen et al. (1993) from the 
Lacepede Shelf and Otway Shelf, respectively. Biogenic sediment in these Celleporaria thickets is multigenerational, representing accumulation from the late Pleistocene to Recent (James et al., 1997; James et al., 2001). The following provides a generalized description of the sediments from Celleporaria thicket facies across the shelf by volume: $>50 \%$ bryozoans (conspicuous large Celleporaria, moderate to low diversity of other erect branching and fenestrate forms, delicate and articulated branching and articulated zooidal forms); $\sim 10 \%$ benthic foraminifera; $5 \%$ planktic foraminifera; $\sim 10 \%$ mollusks, mainly gastropods and scaphopods; $\sim 10 \%$ other bioclasts including abundant ostracodes; $\sim 15 \%$ calcareous mud plus siliceous sponge spicules; locally abundant ahermatypic scleractinian and stylasterine corals growing on substrates of relict Celleporaria (James et al., 1992; Boreen et al., 1993; James et al., 1997; James et al., 2001).

Similarly, isolated biogenic mounds and mound complexes are observed across the western region of the southern margin of the GAB, in water depths of 200-350 m, located just below the shelf margin break Feary and James, 1995; Hine et al., 2000; Bone and James, 2002). These mounds have been dated $\left(\mathrm{C}^{14}\right)$ at 14,000-26,000 ybp (James et al., 2000). Although not currently active (draped by several meters of carbonate mud), the mounds had up to 20-40 m of relief on the sea floor as imaged on seismic profiles (Hine et al., 2000, fig. 2). Mounds with such relief are unknown from Tertiary limestones exposed on shore.

\section{Associated Bryozoan Species Richness at the Shelf Edge}

The modern shelf of southern Australia is characterized by abundant and diverse bryozoan fauna. It is not uncommon to recover more than 70 bryozoan species from a small sediment sample of the mid- to outer-shelf (Hageman et al., 1996; Bock and Hageman, unpublished data). These high-diversity settings are in water depths well below maximum swell wave base. The outer shelf has higher nutrient richness, but nutrient levels are still toward the oligotrophic side of the spectrum (Li et al., 1996a, 1996b).

It is difficult to estimate the species richness within the shelf-edge Pleistocene thickets/mounds at the time of their formation because the relict Celleporaria skeletons are covered with many bryozoans (encrusting and erect) that may have lived among the growing thickets, or may have colonized the skeletons post mortem. In addition, a portion (significance unknown) of the coarse- to very-coarse grained bioclasts, representing a diversity of bryozoans, could be expected to have originated in more shallow water and transported off the shelf onto and filling the thickets (James et al., 2000; James et al., 2001). Although Celleporaria are volumetrically dominant, Bone and James (2002) reported a diverse bryozoan fauna (> 70 genera) associated with buried Pleistocene mounds below the GAB shelf. 


\section{DISCUSSION OF GREAT AUSTRALIAN BIGHT CELLEPORARIA}

The patterns observed from the GAB, Lacepede, and Lincoln Shelves raise several questions. Why are modern, live Celleporaria colonies rare, and found as isolated colonies, but generally restricted to a depth range of 140 to $165 \mathrm{~m}$ ? Why are Late Pleistocene, relict Celleporaria colonies found in abundant thickets at much greater water depth and why are most deep-water GAB Celleporaria (180-350 m) relict forms? Why are many recently dead Celleporaria bioclasts found in moderately shallow water depths $(90-165 \mathrm{~m})$ ? These questions can be addressed by evaluating the environmental parameters that control the distribution of Quaternary Celleporaria in this setting.

The approach taken here was to develop a history of the area based on the correlation of (1) oxygen isotope data (Chappell and Shackleton, 1986), (2) foraminiferal proxies for environments (Table 1), and (3) sedimentological data (James et al., 1992, 1997). These data were used to develop a paleoenvironmental history of the region regarding (1) sea level, (2) ocean currents, and (3) nutrient levels (Table 2). These events can be summarized as a late Pleistocene, glacially driven, sea level low-stand resulting in a mixed water column with more variable nutrient levels, at times eutrophic. The Holocene is represented by a transgression to an interglacial sea level high-stand, resulting in a more stratified water column, with more stable, oligotrophic nutrient levels.

Subsequent to establishing this paleoenvironmental history, the distribution of Celleporaria was plotted in both time (using $\mathrm{C}^{14}$ age dates) and space within this proposed paleoenvironmental model (Table 2). Several physical and biological parameters are of ecological importance to Celleporaria in this environmental model, and are discussed below.

\section{Swell Wave Base}

The distribution of modern and late Pleistocene Celleporaria on the modern southern Australian shelf is strikingly correlated with swell wave base water depths $(\sim 130 \mathrm{~m}$ in this setting, Fig. 7A). The swell wave base here is unusually deep relative to the world average, resulting from the close proximity of the exceptionally high seas derived from the extensive fetch of the circumAntarctic Southern Ocean.

Using a sea level curve for the Pleistocene at this setting (Fig. 8) derived from oxygen isotope data (Chappell and Shackleton, 1986) and the known (modern) water depth from which each 
specimen was collected, actual water depths during the Pleistocene can be estimated for any specimen (i.e., water depth at which relict colonies originally grew). Three $\mathrm{C}^{14}$ dates for relict celleporarid specimens found in thickets off of the Lincoln Shelf are 21,210 ybp, 19,250 ybp, and 14,400 ybp (James et al., 1997). At each of these times, sea level was much lower than it is today. Thus, a 14,400 year old specimen collected in situ from 250 to 300 meters water depth would have grown in a setting with sea level 90 meters lower than today. Therefore, the original water depth in which the colony grew would have been between 160-200 m (Fig. 8). The same calculations can be made for the other two dated, relict specimens. These late Pleistocene mounds initially formed in water depths of 160 to $229 \mathrm{~m}$ (Fig. 8). Note that this is deeper than present day swell wave base, but likely reflects a deeper swell wave base than would be expected from a narrow shelf setting (Hageman et al., 1996). The fact that some live Celleporaria and many recently dead bioclasts were found in shallower water (90-140 m) may also reflect the fact that maximum swell wave depth is a function of the shelf physiography (width and slope), shape of the coast line, and magnitude and fetch of storms (Hageman et al., 1996).

\section{Nutrients}

The movement and exchange of large-scale water masses of variable physical properties (temperature, salinity, and nutrients) are well-documented oceanographic phenomena (Schahinger, 1987; James et al., 1997). However, during high sea level stands, the incursion of stratified water masses from deep ocean onto the shelf are more commonly associated with poorly circulated, rather than nutrient-rich, water masses (Caron and Holmwood, 1983). Upwelling and mixing of water masses on the southern Australian shelf are generally associated with outer shelf during lower sea level stands (Almond et al., 1993; James et al., 2000).

Relict Celleporaria mounds are positioned in the place of present-day upwelling currents, just off of the shelf break (Lewis, 1981; Schahinger, 1987; Wells and Okada, 1996). This setting is presently mesotrophic (Li et al., 1996a, 1996b) and would likely have been even more nutrientrich during the Pleistocene low sea level stand due to increased upwelling and mixing (Tables 1 and 2, Fig. 7B) (Caron and Homewood, 1983; Almond et al., 1993). Although Celleporaria abundance is apparently not the equivalent of a true eutrophic apex taxon, their presence as thickets and mounds is correlative to times of higher nutrient conditions. Celleporarid growth strategy is apparently one of efficient, opportunistic utilization of resources when resources are present (r-mode).

The contrast between late Pleistocene and modern conditions on the shelf is enhanced by the fact that hypersaline, nutrient-poor waters develop on the present-day inner shelf of the GAB 
and produce unproductive down-welling zones (Hine et al., 2000; James et al., 2000). More sample localities across the continental shelf have evidence of dead Celleporaria (sub-recent to relict?), in excess of the number of sample localities with living colonies (Fig. 6). This distribution may reflect a time of more widespread, higher productivity relative to present conditions after/during sea level rise, but before establishment of hypersaline, nutrient-barren, downwelling currents (James et al., 2001).

\section{Sedimentation Rate}

Growth-habit characteristics of Celleporaria are well suited for life in unconsolidated sediment. Their potential for rapid growth from a self-constructed foundation and specialized avicularia for shedding sediment suggest that Celleporaria can survive in environments of relatively continuous sedimentation (i.e., during thicket formation in the late Pleistocene). James et al. (2000) documented surprisingly high sedimentation rates during the Pleistocene, with wave abrasion transporting sediment off the shelf, resulting in Quaternary sediment wedges hosting Celleporaria rich mounds. Concomitant bryozoans in these settings are frequently found using Celleporaria as a substrate.

\section{Summary of Celleporaria and the Quaternary History of the Southern Australian Margin} During the late Pleistocene, approximately 28,000-13,000 ybp, sea level was low (Figs. 7B and 8). Celleporaria formed mounds and thickets in upwelling zones just below the shelf edge across much of the southern margin (Fig. 7B).

Sea level rise during the late Pleistocene transgression ( $\sim 12,000 \mathrm{ybp})$ may have occurred in relatively rapid pulses (Hanebuth et al., 2000), which would account for a rapid shutdown in thicket formation. Evidence for repeated formation of upper-slope Celleporaria mounds throughout the Pleistocene can be observed in ODP seismic and core data (James et al., 2000).

As sea level rose, Celleporaria migrated onto the shelf, presumably remaining below maximum swell wave base. Abundant, dead Celleporaria skeletons are scattered on the mid- to outer shelf (Figs. 5, 6, and 7A), which may reflect a time of more favorable, higher nutrient levels on the shelf.

On the modern mid- to outer shelf, the establishment of an oligotrophic nutrient regime (Figs. 7A and Table 2) and regional down-welling of high-saline, low-nutrient water limit the development of Celleporaria. Development of Celleporaria thickets on the shelf may be possible only in absence of these conditions. 
This distribution through space and time allows for development of a predictive model for environmental distributions of Celleporaria.

\section{MIOCENE CELLEPORARIA THICKETS OF SOUTHERN AUSTRALIA (TERRESTRIAL NUTRIENTS SOURCES?)}

Most of the Cenozoic basins along the southern margin of Australia contain Celleporariabearing limestones. Several basins possess limestones and marls with an abundance of Celleporaria so profuse that they form decimeter-scale thickets, or bafflestones. These Celleporaria-rich units are conspicuous in that they share characteristics among basins, including lithological composition, associated fauna, and meter-scale packaging. Assuming an actualistic application of uniformitarianism, the factors that control the distribution of Quaternary Celleporaria outlined above can be used to interpret the paleoenvironments of these Tertiary basins. However, one is immediately struck by how far inland many of these occurrences are from the continental shelf break. These great distances (exceeding $300 \mathrm{~km}$ ) raise questions for upwelling as the sole control for nutrient levels on epeiric carbonate ramps (Lukasik et. al., 2000).

\section{Murray Basin, South Australia \\ Setting and Materials}

The western Murray Basin (Fig. 1) was the site of a large, shallow inland sea measuring $450,000 \mathrm{~km}^{2}$ throughout the early Neogene (Ludbrook, 1957, 1958, 1961). The thin (<150 m) sequence of Early to Middle Miocene fossiliferous silty limestones and calcareous clays represent generally low-energy deposition on a vast epeiric ramp: a very low-angle to flattopped platform of several 100's of kilometers extent (Lukasik et al., 2000). Rocks are exposed along the River Murray in South Australia for nearly $180 \mathrm{~km}$, offering detailed lithostratigraphic correlation of units (Lukasik and James, 1998).

Fauna of the Oligo-Miocene Murray Basin sediments were surveyed from dozens of measured sections outlined in Lukasik and James (1998). The majority and best-developed Celleporariarich strata are contained within the Miocene Glenforslan Formation, although less-welldeveloped celleporarid-bearing units occur within the overlying Cadell and Bryant Creek formations. A type-reference section of these units (6.4 km S of Morgan) was analyzed in detail for this study (Figs. 1 and 9A, label "III") (Ludbrook, 1958; Lukasik and James, 1998, section 9). Stratigraphic bulk samples collected every $0.5 \mathrm{~m}$ from the Glenforslan through Bryant Creek 
formations were washed and picked for Bryozoa. These strata of the Morgan Group (Lukasik and James, 1998) comprise a 22-25 m upward-shallowing depositional cycle (Fig. 10A) of basal cellarid bryozoan and serpulid worm tube grainstones passing rapidly upward into fossiliferous floatstones and rudstones possessing an abundant and diverse bryozoan fauna, including Celleporaria (Glenforslan Formation). Diversity within these Celleporaria-rich limestones decreases as they are intercalated with muddy, molluscan floatstones of the Cadell Formation (maximum low-stand). These molluscan floatstones are in turn overlain by transgressive, interbedded clays and molluscan-Marginopora rudstones of the Bryant Creek Formation (Lukasik and James, 2000).

\section{Paleoenvironmental Distribution of Murray Basin Celleporaria}

The interpretation of this sequence is one of an offshore to nearshore gradation of facies deposited under progressively higher trophic resources and turbidity in shallowing waters (Lukasik et al., 2000). The Celleporaria limestones of the Glenforslan Formation represent deposition under low-energy, sunlit conditions of a low to high mesotrophic regime. As these units built towards the relatively high mesotrophic to eutrophic units of the overlying Cadell Formation, they became progressively less diverse in bryozoans while becoming more abundant in infaunal molluscs and the large photosymbiont-bearing foraminifer Marginopora (Fig. 10A). It is in these upper Glenforslan Formation beds, where the Celleporaria limestones are intercalated with the muddier, molluscan Cadell Formation facies, that Celleporaria form bafflestones created by thickets of a three-dimensional box-work structure correlatable across an outcrop distance of $70 \mathrm{~km}$.

\section{Terrestrially Derived Nutrient Model for Murray Basin Celleporaria}

Celleporaria beds of the Miocene Murray Basin (Fig. 3C) are found $\sim 300 \mathrm{~km}$ inland from the shelf edge (Figs. 1 and 9A). In addition, the basin is partially barred from the continental shelf by a series of granitic islands/shoals approximately $120 \mathrm{~km}$ inboard of the shelf edge. In this setting, Celleporaria developed mostly during a regression prior to a low stand (Fig. 10A). Water depth of this setting is estimated to be several tens of meters. It would seem virtually impossible to call upon upwelling of ocean waters to provide increased nutrients to this setting. Instead, it is likely that the increase in nutrients was derived from terrestrial sources brought into the system by rivers from the surrounding terrestrial highlands.

Thus, these celleporarid limestones occurred at approximately $20 \mathrm{~m}$ water depth within the transition between slightly deeper $(\sim 50 \mathrm{~m})$, more oligotrophic carbonate deposition and very shallow (few meters deep) subtidal sea grasses to sand flats (Lukasik et al., 2000).

\section{Other Tertiary Celleporaria-Rich Units of Southern Australia}


Cyclic, sub-meter-scale hard bands of Celleporaria alternating with clays or marls occur in many of the Cenozoic basins along the southern margin of Australia (Fig. 3A). In other units through the Tertiary, concentrations of Celleporaria can be observed as incipient beds in cycles of the same scale. Colonies are near their life position (not a lag) and represent early stages of incomplete thicket development.

Well-developed, cyclic Celleporaria beds are documented in the Early Miocene "Cellepora" Beds of the Torquay Group of the Otway Basin in Victoria, Australia (Raggatt and Crespin, 1955; Reeckmann, 1979; Abele, et al., 1988; Webb, 1995; Boreen and James, 1995; Van der Linden, 1997). These cyclic units are of the same scale as those recognized by Li et al. (2003) in the Upper Oligocene Jan Juc Formation and Puebla Clay Formation, which are stratigraphically immediately below the "Cellepora" Beds Member, and are likely associated with fourth order Milankovitch cycles (Li et al., 2003).

\section{Testing the Model: Nutrient Source for Torquay "Cellepora" Beds?}

Two potential sources of nutrients that are required for Celleporaria thickets to develop have been established: (1) upwelling from deep water and (2) terrestrial runoff source in shallow water. The Torquay "Cellepora" Beds can be used as a test case to evaluate paleoecological reconstructions based on the ecological criteria derived from the modern southern Australian shelf and Miocene Murray Basin for deep- versus shallow-water celleporarid thicket formation. An understanding of the temporal succession of environments involved in the (apparently) continuous deposition of the Puebla Formation and units above (Fig. 10B) will provide more information for paleoenvironmental interpretation than will the characteristics of the Puebla Formation alone. Therefore, the transition from the underlying Puebla Clay into the "Cellepora" Beds, and finally into the overlying Zeally and Yellow Bluffs limestones, is presented here.

The traditional interpretation of the sequence is of an overall regression starting with the Puebla Clay (30 m thick) deposited in deep water on the outer to middle shelf below storm wave base (Reeckmann, 1979; Abele et al., 1988; Webb, 1995; Boreen and James, 1995). Foraminifera indicate that the depositional environment of the Puebla Clay was a variable low-oxygen, highnutrient setting (Li et al., 2003). The interpretation for the depositional setting for the "Cellepora" Beds (25 m thick) has varied from shallow marine, inner shelf, 40-60 m (Reeckmann, 1979; M. Warne, unpub. data in Webb, 1995; Beatty et al., 1998), to deep marine, $>100 \mathrm{~m}$ (Boreen and James, 1995). The deep-water interpretation used the Pleistocene deepwater celleporarid thickets off the southern Australian shelf edge as an analog. The overlying Zeally Limestone (25 $\mathrm{m}$ thick) is a cross-bedded, bryozoan grainstone with abundant fragments of echinoids, brachiopods, pectinids, and quartz grains (Webb, 1995; Boreen and James, 1995). The Zeally 
Limestone has been interpreted as having been deposited in a shallow-water, high-energy, inner-shelf environment (Webb, 1995; Boreen and James, 1995).

This interpretation of an overall regression during deposition of the Puebla Formation from outer-shelf deep water to inner-shelf shallow water presents a problem for interpretation of nutrient supply. If the source is upwelling from a deep ocean, the current must cross $120 \mathrm{~km}$ of the continental shelf from the shelf break into the Torquay sub-basin during the relative sea level low stand (Fig. 9B).

An alternative interpretation, proposed here, is that the Puebla Clay was deposited in relatively shallow water in a protected (Stach, 1936) inner-shelf setting, rather than mid-outer shelf. The Puebla Clay was deposited under moderately high sedimentation rate, with some terrestrial input (Fig. 10B). As sea level fell, the "Cellepora" beds formed in a setting just below swell wave base, but close enough to the shore to raise the nutrient level to high mesotrophic levels from terrestrial runoff sources. Evidence for a relatively shallow-water inner shelf during deposition of the Puebla Clay, at the beginning of an overall third order regression, is supported by the following evidence.

\section{Flora and Fauna}

The Puebla Clay, which directly overlies an erosional unconformity with the Jan Juc Formation, is a gray, clayey, calcareous silt (Webb, 1995) with stringer beds of fragmented (but not abraded) bioclasts (lags of storm wash?) dominated by molluscs. For this study, a survey was made of a single 250-mg bulk sample, collected $\sim 20 \mathrm{~m}$ above the base of the formation at Jan Juc Beach, Victoria. The sediment was washed and sieved. The greater than $0.5 \mathrm{~mm}$ size fraction includes the following key taxa indicative of near-shore, calm-water, moderately high sedimentation rates: (1) common, well-preserved, encrusting corallinacean red algae (melebisoid), with a morphology suggesting an epiphytic habit on other shallow-water algae or sea-grass hosts (Abbott and Hollenberg, 1976); (2) common, semi-infaunal bivalve Pinna typical of current-dominated, shallow-water unconsolidated silts to sands (Kauffman, 1969), which is found invariably with sea grasses in modern southern Australian waters, and common epifaunal pectinids and ostreids; (3) Common bivalve genera Tellina and Nuclenia, which are known to be rapid burrowers in unconsolidated silt and sand (Kauffman, 1969; Darragh, 1985; Ludbrook and Gowlett-Holmes, 1989); and (4) a classic bryozoan sand fauna (Cook, 1966), including abundant free-living (Otionella and Selenaria) and rooted (Cellaria and Melicerita) forms. Although these taxa are abundant, overall bryozoan diversity is very low. These sand-fauna bryozoans are adapted to conditions of unconsolidated silt and sand under moderate sedimentation rates, as described from the Rhone delta by Lagaaij and Gautier (1965). Free- 
living forms can dig out and large rooted and articulated forms can slough sediment. The other bryozoan taxa present (very delicate erect branching cyclostomes) indicate a calm-water setting (Stach, 1936).

Other taxa compatible with, but not restricted to, this environment include: (1) abundant turretellid gastropods and scaphopods, which prefer higher nutrient settings, and predatory/scavenger volute and naticid gastropods; (2) a relatively high number of infaunal foraminifera, which also indicate eutrophic conditions (Li et al., 2003); (3) abundant ( $\sim 75 \%$ of specimen count) large, benthic (agglutinated, hyaline, and miliolid) foraminifera (Li et al., 2003); and (4) abundant, well preserved internodes of isidid (articulated branching) octocoral, which indicate calm water in unconsolidated silt (Bayer, 1956).

Other studies that have supported a shallow-water interpretation of this sequence include: (1) calcareous nannofossils (coccolithophores) of genera that are common in the near shore (Helicosphaera, Pontosphaera, Lanternithus, and Zygrhablithus), some of which (Braarudosphaera and Micrantholithus) are extremely rare in open ocean deposits (Siesser, 1979); (2) spicules from nearshore (e.g., Didemnidae ascidians are more abundant in the Puebla Clay than in other Torquay Group strata); and (3) ostracodes in the "Cellepora" Beds, which suggest an inner-shelf water depth of $40 \mathrm{~m}$ (M. Warne, unpub. data in Webb, 1995).

\section{Petrology and Sedimentology}

The presence of glauconite in the Puebla Clay has been interpreted as evidence for slow deposition in deep water (Boreen and James, 1995). However, material examined here suggests that the glauconitic grains are detrital, with no examples of authigenic glauconite within skeletal void space. Glauconite in the Puebla Clay may have been reworked from glauconiterich Eocene or Oligocene units during post-Jan Juc erosion. An enigmatic bed of "septarian limestone" in the upper Puebla Clay (Boreen and James, 1995; Webb, 1995) forms a prominent hard band, $\sim 9 \mathrm{~m}$ from the base of the unit. It actually is a calcite-cemented quartz sandstone, with a likely nearshore source (Reeckmann, 1979). In addition, well-rounded, fine- to coarsegrained quartz sand is present in the Puebla Clay sample analyzed for this study. They are also reported from the "Cellepora" Beds and overlying Zeally Limestone (Webb, 1995; Boreen and James, 1995).

\section{Comparison of the "Cellepora" Beds at Torquay to Paleoenvironmental Conditions of Similar Australian and Tethyan Settings}

Paleoenvironmental interpretations for the Torquay "Cellepora" Beds can be made by comparing characteristics of their depositional environment with conditions described among several Celleporaria thicket-bearing, shallow-marine settings through the Cenozoic. The Middle 
Miocene nearshore, shallow, semi-restricted eutrophic to high-mesotrophic environment with fluctuating oxygen levels (facies M-2 and M-3) of the Murray Basin described by Lukasik et al. (2000, fig. 5, table 3) provide a paleoenvironmental standard to which the Puebla Clay can be compared (Figs. 10, 11). The faunal compositions of the two units are comparable, with the primary difference being that the degree of fragmentation is greater in the Puebla Clay. Virtually all molluscs in the Puebla Clay are fractured, but rarely abraded or encrusted. This suggests that these are storm lags of sediment washed into deeper, otherwise quiet, shallow water. The geometry of the Murray Basin differs from the setting of the Torquay celleporarid thickets in that the Murray Basin is a relatively flat basin, which results in a broad coastal plain. The Torquay and Rhodes settings (see below) had nearby uplands, such that sub-wave-base water depths would have been relatively close to the shoreline and would have received clastic, bioclastic, and nutrient input from adjacent littoral and terrestrial settings.

Celleporaria thickets from the Pliocene on the island of Rhodes (Kolymbia Limestone) have an associated fauna that indicates a water depth of 30-50 m (Spjeldnaes and Moisette, 1997). They are found in a transgressive sequence (Figs. 10 and 11), ranging from silty marl at the base to a Celleporaria thicket to a marl with a more diverse, erect bryozoan fauna on top that rapidly deepens to marine clays above (Spjeldnaes and Moisette, 1997). Isolated fragments of articulated coralline algae and ostreids as well as coarse (littoral) sediment are associated with the marl and Celleporaria bed, indicating a near-shore environment (Spjeldnaes and Moisette, 1997). The units of the Puebla Formation compare to those of the Kolymbia Limestone (Figs. 10,11). The Kolymbia Limestone in Rhodes apparently represents a single, relatively rapid transgression, whereas the Torquay section represents a longer interval over a slower sea level change, with multiple smaller cycles within it.

The Torquay Basin and Rhodes Island (Fig. 11) share the characteristic of having relatively sharp, steep edges (i.e., close adjacent uplands) (Webb, 1995; Spjeldnaes and Moisette, 1997). In contrast, the Murray Basin is a broad, flat epeiric ramp (Lukasik et al., 2000). These geometries affect distance to shore line versus water depth. Therefore, the Torquay Basin and Rhodes Island are able to have low-level, sub-swell-wave base conditions ( $\sim 30-80 \mathrm{~m}$ ) relatively close to the shoreline.

Although comparable facies are not present in the Puebla Formation, the environmental settings described by Gammon et al. (2000) for shallow, warm-water sponge beds with high nutrient sources derived from the continent are perhaps comparable. The Eocene spiculites were probably at a higher trophic level and contained more silica than the depositional environment of 
the Puebla Formation, but the shallow, quiet-water, protected embayments are potentially analogous.

In the Eocene of the St. Vincent Basin, South Australia, the Blanche Point Formation is a nearshore, spiculictic unit (James and Bone, 2000; McGowran and Li, 1997). The Tuketja Member, the lowest member of the Blanche Point Formation, has conspicuous, though not bedded, Celleporaria. This is also interpreted as deposition in a relatively protected, shallowwater environment, with high nutrient content (James and Bone, 2000; McGowran and Li, 1997). This setting fits into the context of the proposed model, as does the bryozoan-rich, middle Eocene Norseman Limestone paleodrainge channels adjacent to the Bremer Basin (Clarke et al., 1996).

\section{Implications for Interpretation of Sea Level Curves in Australian Cenozoic}

The available data suggest that a reevaluation of the environmental depositional setting of the Torquay "Cellepora" Beds and associated units of the Puebla Formation is appropriate. If additional evidence supports near-shore, shallow, quiet water in a protected embayment (rather than deep, outer-shelf, sub-storm wave bases), this would call for a reinterpretation of the correlation of these units with global sea level curves such as Haq et al. (1988).

Similar cyclic beds are also known from the Miocene of the Gippsland Basin (Gallagher and Holdgate, 1996), Middle Miocene of Tasmania (Hageman, unpub. data), and the Eocene of the Ecula Basin (James and Bone, 1994). Incipient beds of Celleporaria bands are also known from the Gambier Limestone, and the St. Vincent Basin.

\section{SUMMARY}

Because Celleporaria have specific physical and biological conditions under which they thrive, they potentially are important paleoenvironmental indicators for depositional environments throughout the Cenozoic of southern Australia. These conditions, however, can be found under different circumstances in different environments (e.g., below swell-wave base in upwelling environments, or in shallow, calm water with terrestrial nutrient source; Fig. 11). Other nutrient sources proposed in the literature (e.g., longshore currents and freshwater seeps) have not been explored here. 
Hollow-branched Celleporaria are epibionts on fistulose sponges. They have growth habit characteristics that allow them to exploit conditions of moderate sedimentation rates in high nutrient settings, below maximum wave depth. Their rapid growth through frontal budding allows formation of large, robust branches in a three-dimensional box-work. Nutrients can be derived from oceanic upwelling or terrestrial runoff (i.e., an environmental condition, not a specific geographic province). Bryozoan faunas that are diverse in oligotrophic conditions in these regions do not thrive at these times.

Deep-water and shallow-water Celleporaria thickets share the following characteristics (regardless of absolute water depth): (1) mesotrophic nutrient regime (intolerant of eutrophic or oligotrophic); (2) substrate of silt or clay with moderately high sedimentation rate; and 3) relatively quiet water, near or below swell wave-base, but below fair-weather wave base.

Deep water and shallow water Celleporaria thickets have these same physical conditions, but found in different environments: (1) nutrient source was from upwelling deep-sea currents for deep-water thickets (it is presently unclear how far onto the shelf these may have extended), whereas shallow-water thickets derive their nutrients from terrestrial runoff; (2) water depth for deep thickets was greater than $160 \mathrm{~m}$, and was likely a function of regional storm intensity and fetch, whereas water depth for shallow-water thickets was likely between 20-40 m, depending on the width of the shelf/ramp and the degree of hydrodynamic protection (islands, embayment); (3) deep-water thickets are associated with overall very low sea level stands, whereas shallowwater thickets occurred toward the end of regressive sequences, or early in transgressive sequences (i.e., just below or above a high stand at the depth of storm-wave base), and (4) associated silt- and clay-sized particles are carbonate in deep water thickets, whereas shallowwater thickets contain terrestrially derived siliciclastic sediment.

Both deep-water and shallow-water Celleporaria thickets provide clues to their position within third order sea level cycles. They represent transitions from maximum low and high stands, respectively (when other environmental requisites are met). Within these settings, Celleporaria thickets appear to be sensitive to 4 th order cycles in sea level. Undoubtedly, further documentation of the successional, environmental distribution of Celleporaria in Cenozoic sediments of southern Australia will provide broader insights into the history of many Cenozoic depositional systems.

\section{Acknowledgments}

We thank P. Bock (Royal Melbourne Institute of Technology, Melbourne) for discussion, N.P. James (Queen's University, Canada), F.K. McKinney (Appalachian State University), and F. Read (Virginia Tech) whose suggestions greatly improved this paper. M. Key and an 
anonymous reviewer provided helpful comments and suggestions. We thank the Marine Invertebrates Section of The South Australia Museum for use of facilities and their assistance, which greatly facilitated this project. We thank L. Hobbs (University of Melbourne) for assistance in sponge identification. This research was funded by the Australian Research Council. We thank CSIRO Division of Oceanography and the captains and crew of the R. V. Franklin for their support during cruises on which these samples were collected.

\section{REFERENCES}

Abbott, I. A. and G. J. Hollenberg. 1976. . Marine Algae of California: Stanford University Press, Stanford, California, $827 \mathrm{p}$.

Abele, C., C. S. Gloe, J. B. Hocking, G. Holdgate, P. R. Kenley, C. R. Lawrence, D. Ripper, and W. F. Threlfall. 1988. Tertiary. in Douglas, G.J, and Ferguson., J.A., eds., The Geology of Victoria, 2nd Edition: Victorian Division of the Geological Society of Australia Inc., Melbourne, p. 252-350.

Almond, D., B. McGowran, and Q. Li. 1993. Late Quaternary foraminiferal record from the Great Australian Bight and its environmental significance. Memoir of the Association of Australian Palaeontologists 15:417-428.

Banta, W. C. 1972. The body wall of Cheilostome Bryozoa, V. Frontal budding in Schizoporella unicornis floridana. Marine Biology 14:63-71.

Bayer, F. M. 1956. Octocorallia. in Moore, R.C., ed., Treatise on Invertebrate Paleontology, Part F, Coelenterata: The Geological Society of America, Inc. and The University of Kansas, Lawrence, Kansas, p. F166-F231.

Beatty, W. L., R. J. Cuffey, S. J. Hageman, and A. M. Smith. 1998. Paleodepth and paleohabitat from bryozoan colony growth forms (Early Miocene, southern Australia). Geological Society of America Abstracts with Programs 30:4,. 2.

Berger, W. H. and L. Diester-Haass. 1988. Paleoproductivity; the benthic/planktonic ratio in foraminifera as a productivity index. Marine Geology 81:15-25.

Boltovskoy, E. and R. Wright. 1976. Recent Foraminifera (second edition). Dr. W. Junk b.v., The Hague, Netherlands, 515 p.

Bone, Y. and N. P. James. 1993. Bryozoans as carbonate sediment producers on the coolwater Lacepede Shelf, southern Australia. Sedimentary Geology 86:247-271. 
Bone, Y. and N. P. James. 2002. Bryozoans from temperate Pleistocene deep-water mounds, Great Australian Bight, Australia. in Wyse Jackson, P.N., Buttler, C.J., and Spencer Jones, M.E., eds., Bryozoan Studies 2001, Proceedings of the Twelfth International Bryozoology Association Conference: A. A. Balkema, Lisse, p. 53-59.

Boreen, T. J. and N. P. James. 1995. Stratigraphic sedimentology of Tertiary cool-water limestones, SE Australia. Journal of Sedimentary Research B65. 142-159.

Boreen, T. J., N. P. James, C. Wilson, and D. Heggie. 1993. Surficial cool-water carbonate sediments on the Otway continental margin, southeastern Australia. Marine Geology 112:3556.

Bradstock, M. and D. P. Gordon. 1983. Coral-like bryozoan growths in Tasman Bay, and their protection to conserve commercial fish stocks. New Zealand Journal of Marine and Freshwater Research 17:159-171.

Canu, F. and R. A. Bassler. 1920. North American early Tertiary Bryozoa. United States National Museum Bulletin, v. 106, 879 p.

Caron, M. and P. Homewood. 1983. Evolution of early foraminifers. Marine Micropaleontology 7:453-462.

Chappell, J. and N. J. Shackleton. 1986. Oxygen isotopes and sea level. Nature 324:137-140.

Clarke, J. D. A., Y. Bone, and N. P. James. 1996. Temperate bryozoan limestones in Eocene drowned estuaries, Bremer Basin, Western Australia. Sedimentary Geology 101:213-226.

Cook, P. L. 1966. Some "sand fauna" Polyzoa (Bryozoa) from eastern Africa and the northern Indian Ocean. Cahiers de Biologie Marine 7:207-223.

Corliss, B. H. 1985. Microhabitats of benthic foraminifera within deep-sea sediments. Nature 314:435-438.

Corliss, B. H. and C. Chen. 1988. Morphotype patterns of Norwegian Sea deep-sea benthic foraminifera and ecological implications. Geology 16:716-719.

Cummings, S. G. 1975. Zooid regression in Schizoporella unicornis floridana (Bryozoa, Chielsostomata). Chesapeake Science 16:93-103.

Darragh, T. A. 1985. Molluscan biogeography and biostratigraphy of the Tertiary of southeastern Australia. Alcheringa 9:83-116. 
Feary, D. A. and N. P. James. 1995. Cenozoic biogenic mounds and buried Miocene (?) barrier reef on a predominantly cool-water carbonate continental margin-Eucla Basin, western Great Australian Bight. Geology 23:427-430.

Gallagher, S. and G. R. Holdgate. 1996. Sequence stratigraphy and biostratigraphy of the onshore Gippsland Basin, S.E. Australia: an excursion guide for the Gippsland Basin Symposium '95, University of Melbourne, School of Earth Sciences, 3-5 November, 1995. Australasian Sedimentologists Group Field Guide Series, No. 7, Geological Society of Australia, $83 \mathrm{p}$.

Gammon, P. R., N. P. James, and A. Pisera. 2000. Eocene spiculites and spongolites in southwestern Australia: not deep, not polar, but shallow and warm. Geology 28:855-858.

Hageman, S. J., P. E. Bock, Y. Bone, and B. McGowran. 1998. Bryozoan growth habits: classification and analysis. Journal of Paleontology 72:418-436.

Hageman, S. J., Y. Bone, B. McGowran, and N. P. James. 1996. Bryozoan species distribution on the cool-water Lacepede Shelf, southern Australia. in Gordon, D.P., Smith, A.M, and GrantMackie, J.A., eds., Bryozoans in Space and Time, Proceedings of the $10^{\text {th }}$ International Bryozoology Conference, Wellington, New Zealand: National Institute of Water and Atmospheric Research Ltd, Wellington, p. 109-116.

Hanebuth, T., K. Stattegger, and P. M. Grootes. 2000. Rapid flooding of the Sunda Shelf: a lateglacial sea-level record. Science 288:1033-1035.

Haq, B. U., J. Hardenbol, and P. R. Vail. 1988. Mesozoic and Cenozoic chronostratigraphy and cycles of sea-level change. in Wilgus, C.K., Hastings, B.S., Kendall, C.G.St.C., Rosamentier, H.W., Ross, C.A., and Van Wagoner, J.C., eds., Sea-Level Changes: An Integrated Approach, Society for Economic Paleontologists and Mineralogists Special Publications no. 42, Society for Economic Paleontologists and Mineralogists, Tulsa, p. 71-109.

Hine, A. C., D. A. Feary, M. J. Malone, M. Andres, C. Betzler, G. R. Brooks, C. A. Brunner, M. D. Fuller, A. E. Holbourn, M. Huuse, A. R. Isern, N. P. James, B. C. Ladner, Q. Li, H. Machiyama, D. J. Mallinson, H. Matsuda, R. M. Mitterer, G. R. S. Molina, C. Robin, J. L. Russell, S. Shafik, J. A. T. Simo, P. L. Smart, G. H. Spence, F. Surlyk, P. K. Swart, and U. G. Wortmann. 2000. Research in Great Australian Bight yields exciting early results. EOS 80:521, 525-526.

James, N. P. and Y. Bone. 1994. Paleoecology of cool-water, subtidal cycles in mid-Cenozoic limestones, Eucla Platform, southern Australia. PALAIOS 9:457-476. 
James, N. P. and Y. Bone. 2000. Eocene cool-water carbonate and biosiliceous sedimentation dynamics, St. Vincent Basin, South Australia. Sedimentology 47:761-786.

James, N. P., Y. Bone, L. B. Collins, and T. K. Kyser. 2001. Surficial sediments of the Great Australian Bight: facies dynamics and oceanography on a vast cool-water carbonate shelf. Journal of Sedimentary Research 7:549-567.

James, N. P., Y. Bone, S. J. Hageman, D. A. Feary, and V. A. Gostin. 1997. Cool-water carbonate sedimentation during the terminal Quaternary sea-level cycle: Southern Australia. in James, N.P., and Clarke, A.D., eds., Cool-water Carbonates: SEPM (Society for Sedimentary Geology) Special Publication No. 56, p. 53-75.

James, N. P., Y. Bone, C. C. von der Borch, and V. A. Gostin. 1992. Modern carbonate and terrigenous clastic sediments on a cool-water, high energy, mid-latitude shelf; Lacepede Shelf, southern Australia. Sedimentology 34:877-904.

James, N. P., D. A. Feary, F. Surlyk, J. A. Simo, C. Betzler, A. E. Holbourn, Q. Li, H. Matsuda, H. Machiyama, G. R. Brooks, M. S. Andres, A. C. Hine, and M. J. Malone. and the ODP Leg 182 Science Party,. 2000. Quaternary bryozoan reef mounds in cool-water, upper slope environments: Great Australian Bight. Geology 28:647-650.

Kauffman, E. G. 1969. Form, function, and evolution. in Moore, R.C., and Teichert, C., eds., Treatise on Invertebrate Paleontology, Part N, Mollusca 6, Bivalvia, v. 1: The Geological Society of America, Inc. and The University of Kansas, Lawrence, Kansas, p. N130-N224.

Lagaaij, R. and Y. V. Gautier. 1965. Bryozoan assemblages from marine sediments of the Rhone delta, France. Micropaleontology 11:39-58.

Lewis, R. K. 1981. Seasonal upwelling along the south-eastern coastline of South Australia. Australian Journal of Marine and Freshwater Research 32:843-854.

Li, Q., P. J. Davies, B. McGowran, and T. Van der Linden. 2003. Foraminiferal ecostratigraphy of Late Oligocene Sequences, southeastern Australia: patterns and inferred sea levels at thirdorder and Milankovitch scales. in Olson, H.C., and Leckie, R.M., eds., Micropaleontologic Proxies for Sea-Level Change and Stratigraphic Discontinuities: SEPM Special Publication no. 75, SEPM, Tulsa.

Li, Q., B. McGowran, N. P. James, and Y. Bone. 1996a. Foraminiferal biofacies on the midlatitude Lincoln Shelf, South Australia: oceanographic and sedimentological implications. Marine Geology 129:285-312. 
Li, Q., B. McGowran, N. P. James, Y. Bone, and J. H. Cann. 1996b. Mixed foraminiferal biofacies on the mesotrophic, midlatitude Lacepede Shelf, South Australia. PALAIOS 9:176191.

Lidgard, S. 1985. Zooid and colony growth in encrusting cheilostome bryozoans. Palaeontology 28:26-31.

Lidgard, S. and J. B. C. Jackson. 1989. Growth in encrusting cheilostome bryozoans: I. Evolutionary trends: Paleobiology 15:255-282. CSA

Lipps, J. H. 1979. The ecology and paleoecology of planktic foraminifera. in Lipps, J.H., Berger, W.H., Buzas, M.A., Douglas, R.G., and Ross, C.A., eds., Foraminiferal Ecology and Paleoecology, SEPM Short Course, no. 6: Society of Sedimentary Geology, Tulsa, p. 62-104.

Lipps, J. H. 1987. Prokaryotes and protists. in Broadhead T.W., ed., Fossil Prokaryotes and Protists; Notes for a Short Course: Studies in Geology, University of Tennessee, Department of Geological Sciences, Knoxville, p. 62-104.

Ludbrook, N. H. 1957. A reference column for the Tertiary sediments of the South Australian portion of the Murray Basin. Royal Society of New South Wales Journal and Proceedings 90:174-180.

Ludbrook, N. H. 1958. The type section of the Morgan Limestone and Cadell Marl lens, 4 miles south of Morgan. South Australian Department of Mines and Energy Report 47..

Ludbrook, N. H. 1961. Stratigraphy of the Murray Basin in South Australia. Geological Survey of South Australia Bulletin 36. 96 p.

Ludbrook, N. H. and K. L. Gowlett-Holmes. 1989. Chitons, gastropods, and bivalves. in Shepherd, S.A., and Thomas, I.M., eds., Marine Invertebrates of South Australia Part II: South Australian Government Printing Division, Adelaide, South Australia, p. 504-724.

Lukasik, J. J. and N. P. James. 1998. Lithostratigraphic revision and correlation of the OligoMiocene Murray Supergroup, western Murray Basin, South Australia. Australian Journal of Earth Sciences 45:889-902.

Lukasik, J. J., N. P. James, B. McGowran, and Y. Bone. 2000. An epeiric ramp: low-energy, cool-water carbonate facies in a Tertiary inland sea, Murray Basin, South Australia.

Sedimentology 47:851-881. 
McGowran, B. and Q. Li. 1997. Stratigraphic Excursion to Maslin and Aldinga Bays. University of Adelaide, Adelaide, $41 \mathrm{p}$.

Moistett, P. and S. Pouyet. 1991. Bryozoan masses in the Miocene, Pliocene and Holocene of France, North Africa and the Mediterranean. in Bigey, F.P., ed., Bryozoa Living and Fossil: Nantes, Bulletin de la Société de Sciences Naturelles de l'Quest de la France, Memior 1, p. 271-279.

Pouyet, S. 1973. Révision systématique des Cellépores (Bryozoa, Cheilostomata) et des espéces fossiles Européennes. Analyse de quelques populations a Cellépores dans le Néogéne du Bassin Rhodanien. Documents des Laboratoires de Géologie de la Faculté des Sciences de Lyon, n. 55, 266 p.

Raggatt, H. G. and I. Crespin. 1955. Stratigraphy of Tertiary rocks between Torquay and Eastern View, Victoria. Proceedings of the Royal Society of Victoria 67:75-142.

Reeckmann, S. A. 1979. Detailed stratigraphy of the Tertiary rocks between Torquay and Eastern View, Victoria: facies, environment and diagenesis. Unpublished Ph.D. dissertation, School of Earth Sciences, University of Melbourne, Australia, 318 p.

Rider, J. and R. Cowen. 1977. Adaptive architectural trends in encrusting ectoprocts. Lethaia 10:29-41.

Schahinger, R. B. 1987. Structure of coastal upwelling events observed off of the south-east coast of South Australia during February 1983-April 1984. Australian Journal of Marine and Freshwater Research 38:439-459.

Siesser, W. G. 1979. Oligocene-Miocene calcareous nannofossils from the Torquay Basin, Victoria, Australia. Alcheringa 3:159-170.

Spjeldnaes, N. and P. Moissette. 1997. Celleporid (Bryozoan) thickets from the Upper Pliocene of Rhodes. in James, N.P., and Clarke, A.D., eds., Cool-water Carbonates: SEPM (Society for Sedimentary Geology) Special Publication No. 56, 263-270.

Stach, L. W. 1936. Correlation of zoarial form with habitat. Journal of Geology 44:60-65. CrossRef

Vand der Linden, T. 1997. Depositional facies, cyclicity and sequence stratigraphy of the OligoMiocene Torquay Basin, southeastern Australia. Unpublished MSc thesis, The University of Sydney, $331 \mathrm{p}$. 
Webb, J. A. 1995. Cool-water Carbonates of the Northeastern Otway Basin, Southeastern Australia: Excursion Guide for Cool and Cold-water Carbonate Conference, Geelong, Victoria, 14-19 January, 1995. Australasian Sedimentologists Group Field Guide Series, No. 6, Geological Society of Australia, $60 \mathrm{p}$.

Wells, P. and H. Okada. 1996. Holocene and Pleistocene glacial palaeoceanography off southeastern Australia, based on foraminifers and nannofossils in Vema cored hole V18-222. Australian Journal of Earth Sciences 43:509-523.

\section{APPENDIX}

Samples (living and benthic sediment) were collected from four voyages of the RV Franklin (1989, 1991, 1994, 1995), which sampled sediments across transects of the continental shelf and upper slope (30-600 $\mathrm{m}$ ) from a region from eastern South Australia to the southwest shelf off Western Australia (Fig. 5). Data for this study are concentrated on material collected from the Southwest Shelf and Great Australian Bight (142 samples). Sediment samples collected with a Blay's pipe dredge on South Australian cruises $(1989,1991,1994)$ are used to characterize these regions. Fossil material was collected from a variety of Cenozoic formations across southern Australia.

Taxonomy of Celleporaria (Lepraliellidae, Cheilostomata) Sturt 1832, p. 253, t. 3, f. 1. (as Eschara celleporacea)

The taxonomy of celleporarid bryozoans is especially problematic. Members of this genus display a great deal of plasticity in their morphologic expression. In addition, key morphological features such as aperture shape and development of avicularia can be observed only during different times of the development of a zooid (ontogeny). Careful scanning electron microscopy of multiple colonies is required for accurate species identification. The literature is filled with species names derived from incomplete study of the group. There are at least two and possibly as many as seven modern species, under the name Celleporaria oculata (typically used for living, southern Australian specimens with this growth habit). A complete systematic revision of the Australian members of the genus Celleporaria is beyond the scope and goals of this paper, however, relevant taxa are illustrated and briefly discussed here to provide for communication purposes within this paper (Fig. 5). 
Most fossil specimens of this group are assigned to the name Celleporaria gambierensis, although there are clear differences among Eocene, Oligo-Miocene and Modern forms. These are similar to, but different than C. palmata, which forms thickets in the Pliocene of the Mediterranean (Spjeldnaes and Moissette, 1997).

\section{Bibliography of Literature Relevant to the Taxonomy of Living and Fossil Celleporaria of Southern Australia}

BASSLER, R.S., 1953, Bryozoa, in Moore, R. C., ed., Treatise on Invertebrate Paleontology, Part G: Geological Society of America and University of Kansas Press, Lawrence, 253 p.

BISHOP, J.D.D, AND HAYWARD, P.J., 1989, SEM atlas of type and figured material from Robert Lagaaij's 'The Pliocene Bryozoa of the low countries' (1952): Mededelingen Rijks Geologische Dienst, v. 42, 64 p.

Bock, P.A., 1982, Bryozoans (Phylum Bryozoa), in Shepherd, S.A. and Thomas, I.M., eds., Marine Invertebrates of Southern Australia, Part I: Government Printer, South Australia, p. 319394.

Brown, D.A., 1952, The Tertiary Cheilostomatous Polyzoa of New Zealand: Trustees of the British Museum (Natural History), London, 405 p.

Busk, G., 1860, Note on the fossil Polyzoa collected by the Rev. J. E. Woods near Mount Gambier, South Australia: Quarterly Journal of the Society of London, v. 16, p. 260-261.

BuSK, G., 1860, Zoophytology: catalogue of the Polyzoa collected by J.Y. Johnson, Esq., at Madeira, in the years 1859 and 1860, with descriptions of the new species: Quarterly Journal of Microscopical Science, v. 8, p. 280-285. [First use of “Cellepora gambierensis"]

BuSK, G., 1881, Descriptive catalogue of the species of Cellepora collected on the "Challenger" Expedition: Journal of the Linnean Society, Zoology, v. 15, p. 341-356.

CAULET, M.J., 1970, Les sediments organogenes du precontinent algerien: Memoires du Museum National d'History Naturelle, Paris, v. 25, 289 p.

GoRDON, D.P., 1984, The marine fauna of New Zealand: Bryozoa: Gymnolaemata from the Kermadec Ridge: New Zealand Oceanographic Institute Memoir, v. 91, 198 p. 
GoRDON, D.P., 1989, The marine fauna of New Zealand: Bryozoa: Gymnolaemata (Cheilostomida Ascophorina) from the western South Island continental shelf and slope: New Zealand Oceanographic Institute Memoir, v. 97, 158 p.

Gordon, D.P., STUART, I.G., and Collen, J.D., 1994, Bryozoan fauna of the Kaipuke Siltstone, northwest Nelson: a Miocene homologue of the modern Tasman Bay coralline bryozoan grounds: New Zealand Journal of Geology and Geophysics, v. 37, p. 239-247.

HARMER, S.F., 1957, The Polyzoa of the Siboga Expedition, Part 4. Cheilostomata Ascophora II: Uitkomsten op Zoologisch, Botanisch, Oeanographisch en Geologisch Gebied versameld in Nederlandsch Oost-Indie, 1899-1900, v. 28d, p. 641-1147.

LAMARCK, J.B.P.A., 1815, Histoire Naturelle des Animaux sans Vertebres: Verdière, Paris, 568 p. [Description of the species C. oculata, p. 171]

LAMOUROUX, J., 1821, Exposition methodique des genres de l'ordre des Polypiers avec leur description et celle des principales especes, figurees dan 84 planches; les 63 premieres apprtenant a l'Histoire naturelle des Zoophytes d'Ellis et Solander: Agasse edit., Paris, 115 p. [First description of the genus Celleporaria]

McCoY, F., 1874, Prodromus of the Paleontology of Victoria, or Figures and Descriptions of Victorian Organic Remains: Geological Survey of Victoria, J. Ferres, Govt. Printer, Melbourne.

MACGILLIVRAY, P.H., 1895, A monograph of the Tertiary Polyzoa of Victoria: Transactions of the Royal Society of Victoria New Series, v. 4, 166 p.

MOISSETTE, P., 1993, Bryozoan assemblages in Messinian deposits of western Algeria: Lethaia. v. 26 , p. 247-259.

POUYET, S., 1973, Revision systematique des cellepores (Bryozoa, Cheilostomata) et des especes fossiles Europeennes. Analyse de quelques populations a cellepores dans le Neogene du Bassin Rhodanien: Documents des Laboratoires de Geologie de la Faculte des Sciences de Lyon, n. 55, 266 p.

POUYET, S., 1978, Revision de quatre especes actuelles de Celleporaria (Bryozoa, Cheilostomata) decrites par de Lamarck en 1816: Geobios, v. 11, p. 611-621.

StOLICZKA, F., 1865, Fossile Bryozoen aus dem tertiären Grünsandsteine der Orakei-Bay bei Auckland. Reise der Österreichischen Fregatte "Novara" um die Erde in den Jahren 1857, 1858, 1859: Geologischer Theil 1 (2 (1 Band, 1 Abth., No. 4)), p. 89-158. 
STURT, C., 1832, Two Expeditions to Interior of South Australia. Volume II: Smith, Elder and Cornell, London, 253 p. [First description of C. gambieriensis as "Eschara celleporacea"]

TENISON-WoOdS, J.E., 1860, On the Tertiary deposits at Portland Bay, Victoria: Transactions of the Philosophical Institute of Victoria (=Royal Society) v. 4,2, p. 169-172.

TENISON-WoOdS, J.E., 1862, Geological Observations in South Australia: Longman, Green \& Co, London, $404 \mathrm{p}$.

TENISON-WoOdS, J.E., 1865, On some Tertiary fossils in South Australia: Transactions and Proceedings of the Royal Society of New South Wales, v. 6, p. 3-6. [Description of Cellepora gambieriensis]

TENISON-WoOdS, J.E., 1876, On some Tertiary fossils from Table Cape, Tasmania: Papers and Proceedings of the Royal Society of Tasmania (for 1875), p. 14.

TENISON-WoodS, J.E., 1877, On some Tertiary Australian Polyzoa: Journal and Proceedings of the Royal Society of New South Wales, v. 10, p. 147-150.

WASS R.E., CONOLLY, J.R. and MACINTYRE R.J., 1970, Bryozoan carbonate sand continuous along southern Australia: Marine Geology, v. 9, p. 63-73.

WASS, R.E., and Yoo, J.J., 1975, Bryozoa from Site 282 west of Tasmania, in Kennett, J.R., Houtz, R.E., Andrews, P.B., Edwards, V.P., Gostin, V.A., Hajos, M., Hampton, M.A., Jenkins, D.G., Margolis, S.V., Ovenshire, A.T., and Perch-Nielsen, K., eds., Initial Reports of the Deep Sea Drilling Project, Volume 29: U.S. Government Printing Office, Washington, p. 809-831.

WASS, R.E., and YOO, J.J., 1983, Cheilostome Bryozoa from the southern Australian continental shelf: Australian Journal of Marine and Freshwater Research, v. 34, p. 303-354.

WATERS, A.W., 1887, Bryozoa from New South Wales, North Australia: Annals and Magazine of Natural History, Series 5, v. 20, p. 181-203.

WILKINSON, C.S., 1865, A geological report on Cape Otway District: Geological Survey of Victoria, Melbourne, folio.

UtLEY, G.H., and BuLLIVANT, J.S., 1971, Biological results of the Chatham Islands 1954 expedition, part 7, Bryozoa, Cheilostomata: New Zealand Oceanographic Institute Memoir, n. $57,61 \mathrm{p}$. 
FIGURES \& TABLES

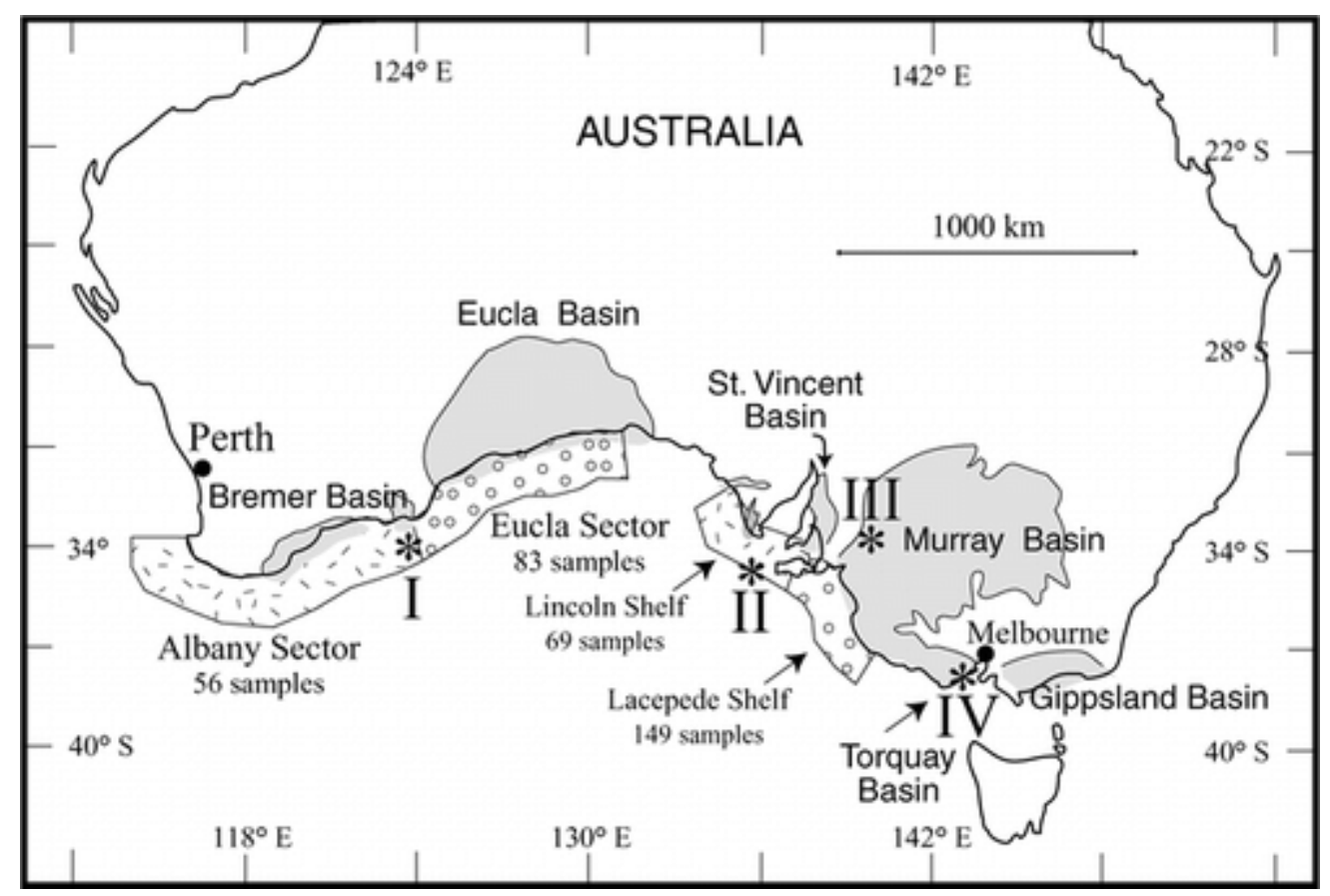

FIGURE 1-Southern Australian Cool-water Province; sampled shelves and Cenozoic Basins. Asterisks labeled I, II, III, and IV indicate the locations of samples in this study used to develop idealized models for Celleporaria thicket formation. These positions correspond to labels I, II, III, and IV in Figs. 7, 9, 10, and 11. Fill patterns on the shelf designate field areas (e.g., Albany sector (Fig. 5A) and Eucla sector (Fig. 5B) of the GAB) 

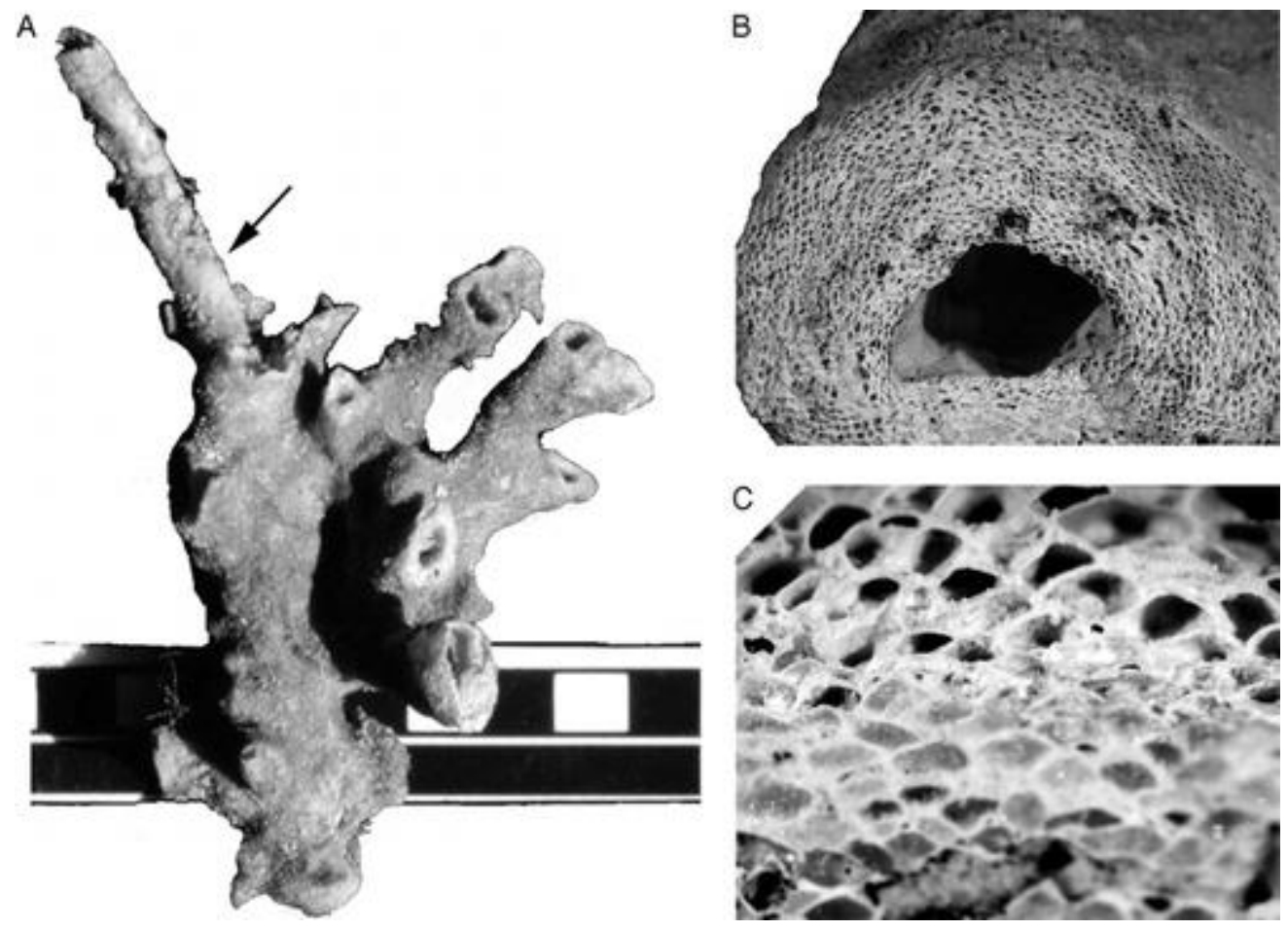

FIGURE 2-(A) Live Celleporaria sp. from GAB (Site GAB-119). Arrow indicates sponge (Oceanapia sp.) extending beyond end of colony. Other branches display hollow tubes that have grown beyond the sponge (scale in $\mathrm{cm}$ ). (B) Middle Miocene Celleporaria sp. (Gippsland Basin) illustrating multilaminate, frontally budded zooids and hollow branch (frame width 2.3 $\mathrm{cm}$ ). (C) Close up of specimen (B) illustrating multilaminate, frontally budded zooids and varying degrees of void-filling calcite cement within zooecial (frame width $0.65 \mathrm{~cm}$ ) 

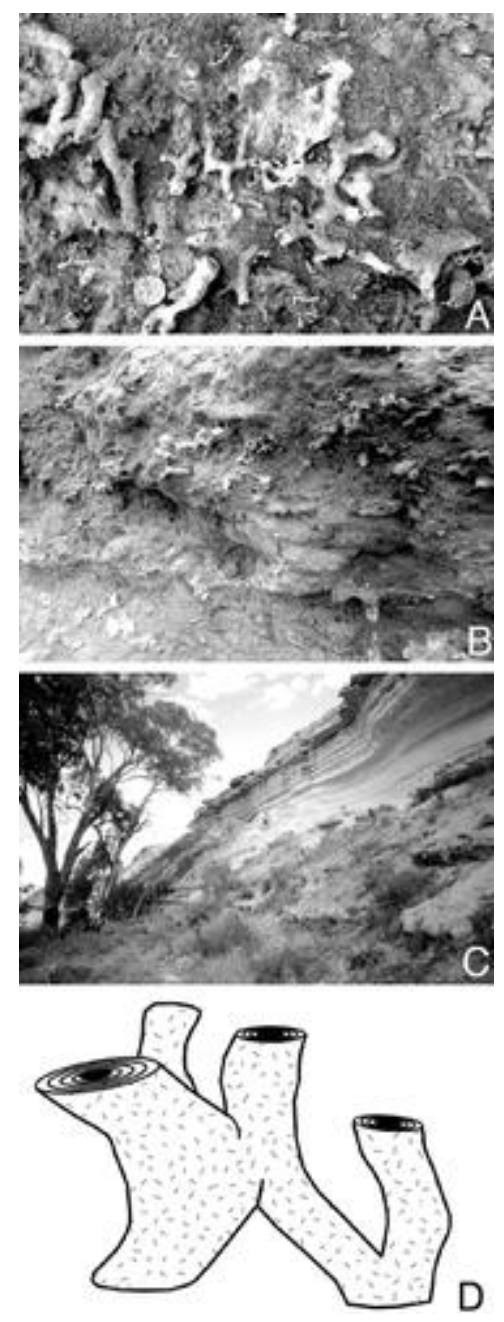

FIGURE 3-(A-B) Celleporaria thickets from "Cellepora" beds of Puebla Formation, Torquay, Victoria, Australia; label "IV" (Middle Miocene) on Fig. 1. (A) Top view of a bed with anastomosing box-work colonies weathered in relief; coin $=2 \mathrm{~cm}$. (B) Lateral view of a Celleporaria thicket or bed, approximately $30 \mathrm{~cm}$ thick; hammer head $=15 \mathrm{~cm}$. (C) Sub-meter scale cyclic beds (long arrows) of the Glenforslan Formation of the Morgan Group, Morgan Bend in Murray Basin, South Australia; label "III" on Fig. 1. Short arrows highlight beds of Celleporaria thickets that form ledges. Overall regressive to transgressive sequence centered on dark recessive bed, upper right. (D) Idealized sketch of the three-dimensional, anastomosing, fused growth habit of Celleporaria 

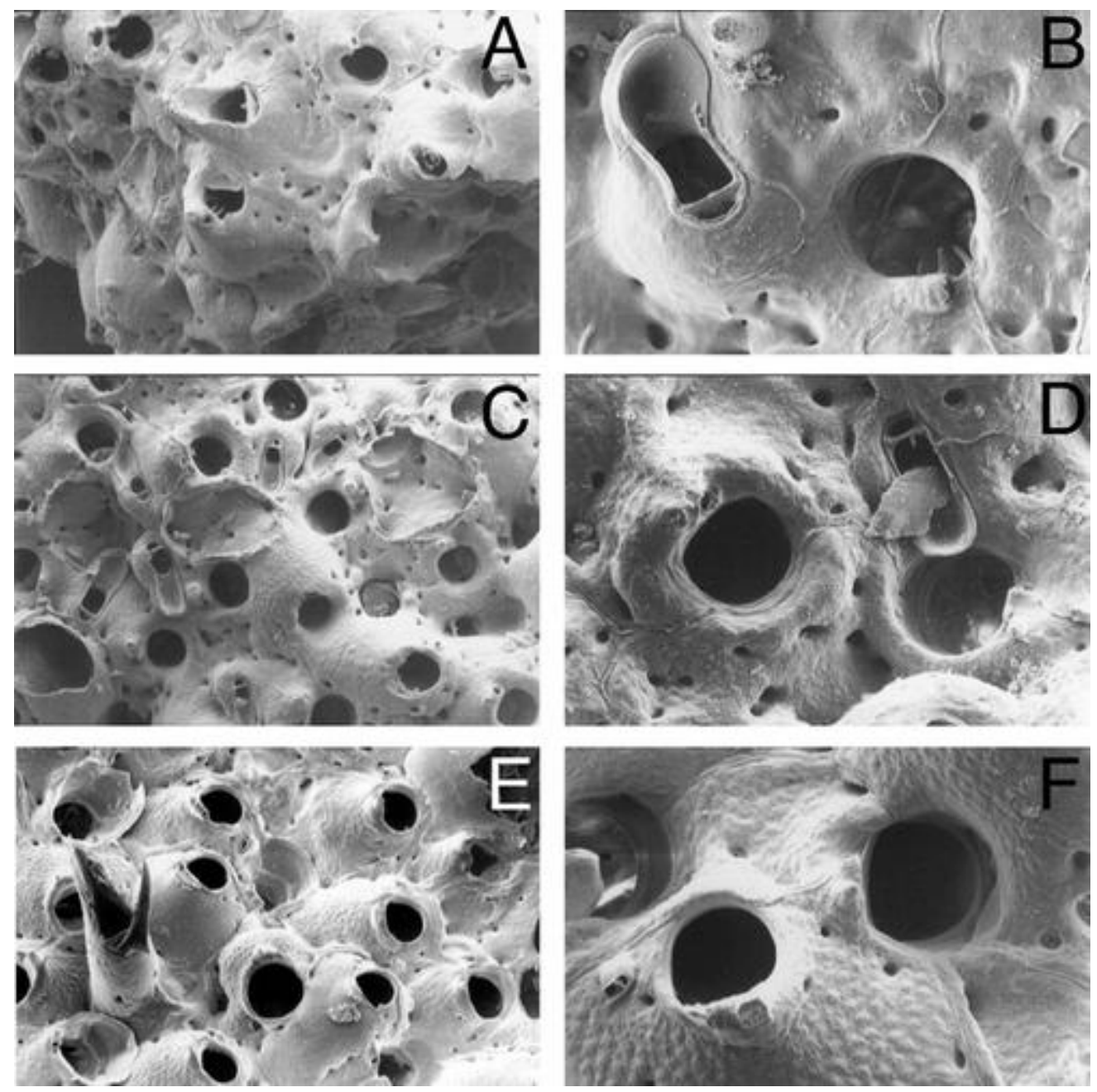

FIGURE 4-Three species(?) (A-B; C-D; E-F) of modern Celleporaria from the GAB (A, C, E47x; $B, D, F-125 x)$. Taxonomic concepts for species within the genus are unclear due to the high degree of variability both within and among colonies, including irregular orientation of zooids emplaced at variable levels on the colony surface; variability of vicarious avicularia from spatulate $(B)$, to sharply lancellate $(E)$, and avicularia elevated on pedestals $(A)$ to below the overall colony surface (D); variable appearance of brood chambers $(E, F)$; and variable thickening of frontal walls and surface texture; $(B)$ is a thick wall and $(F)$ is a thin wall. 

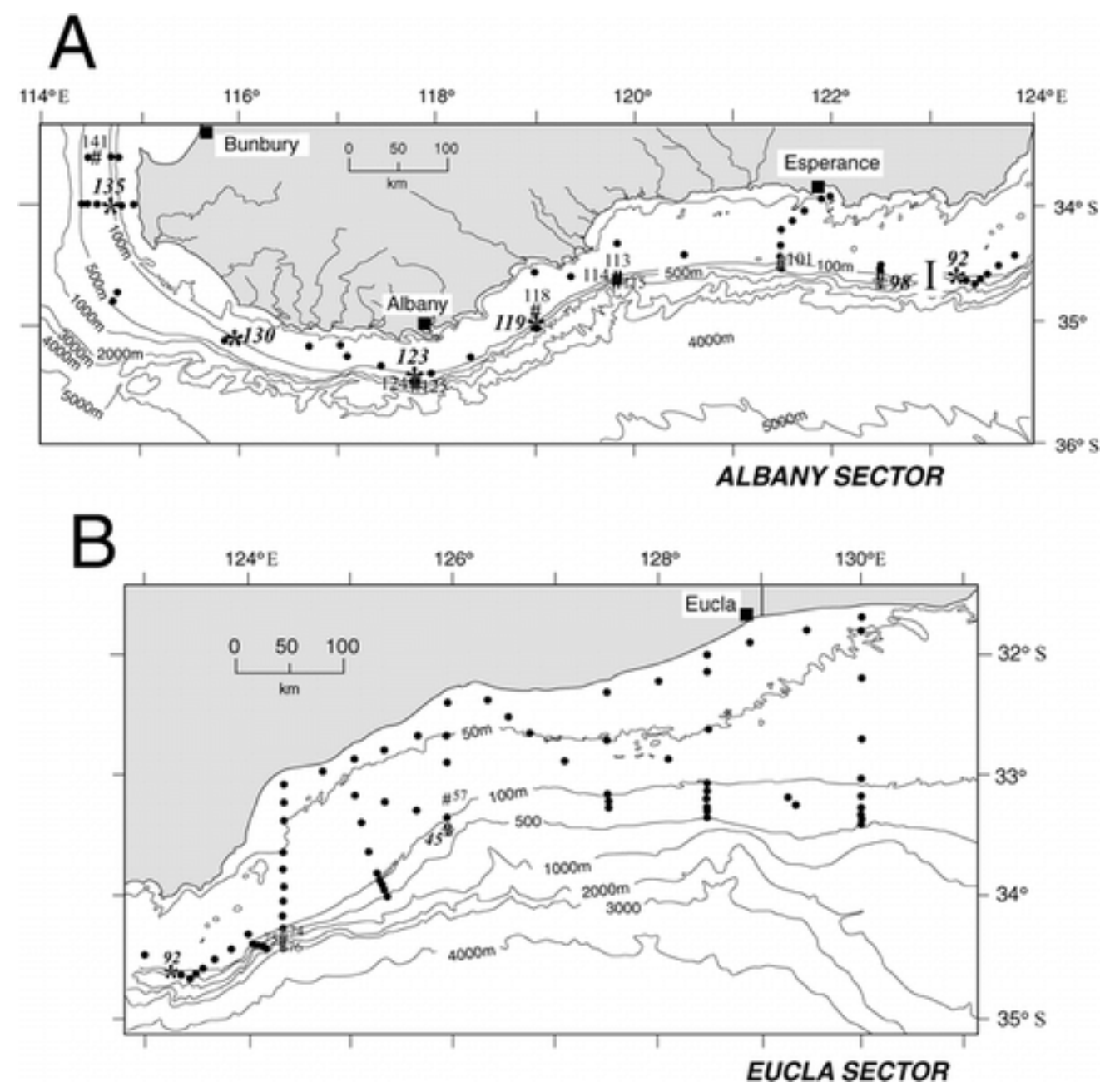

FIGURE 5-Great Australian Bight (GAB) sample localities. Numbers are designated GAB sample sites (Y. Bone, unpublished data); those in large italic fonts and labeled with "*" designate live samples of Celleporaria; those in smaller fonts and labeled with "\#" designate where dead and/or relict samples of Celleporaria were collected, unnumbered sites, designated with "•", are sites where no hollow-branched Celleporaria were found. (A) Albany Sector. (B) Eucla Sector 


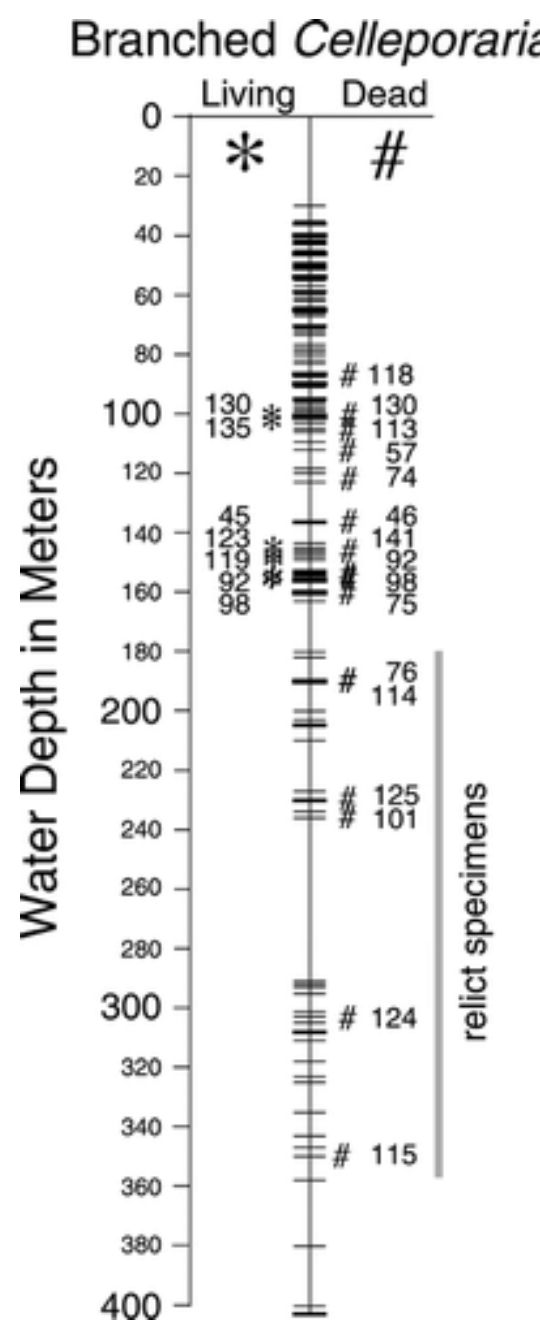

FIGURE 6-Water-depth distribution of GAB sample localities; each crossbar corresponds to a sample site in Fig. 5. Samples with living Celleporaria are labeled by sample number and "*" in the left column. Samples with non-living Celleporaria are labeled by sample number and "\#" in the right column. Sites with no hollow-branched Celleporaria are designated by unlabeled crossbars 


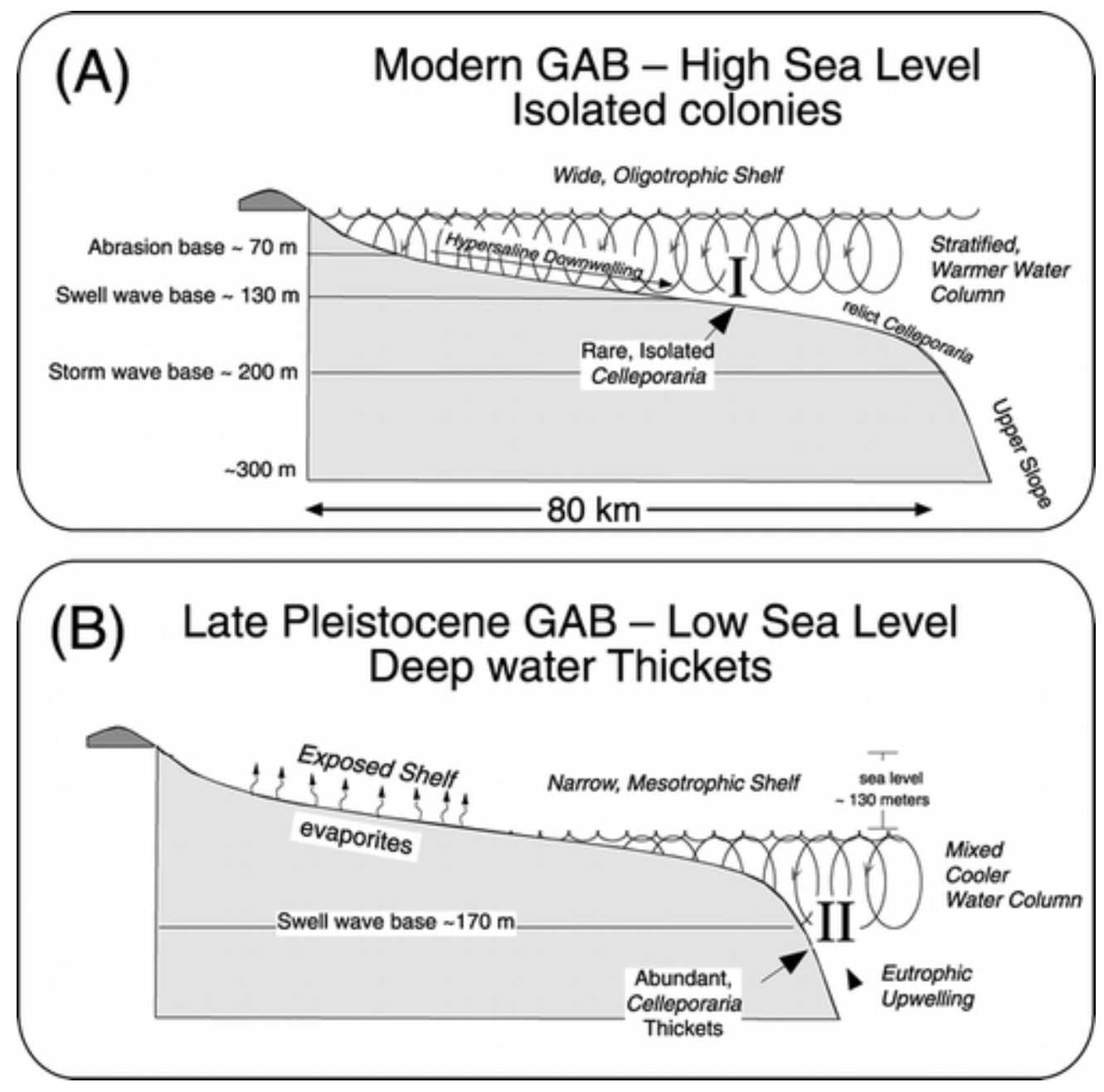

FIGURE 7-Generalized diagrams of the GAB, southern Australian shelf profiles (continent to left, Southern Ocean to right). Labels I and II correspond to the geographic location of Celleporaria thickets denoted by labeled asterisks on Fig. 1. (A) Profiles of high, modern and (B) low, late Pleistocene sea level stands illustrate differences in environmental parameters and location of Celleporaria growth 


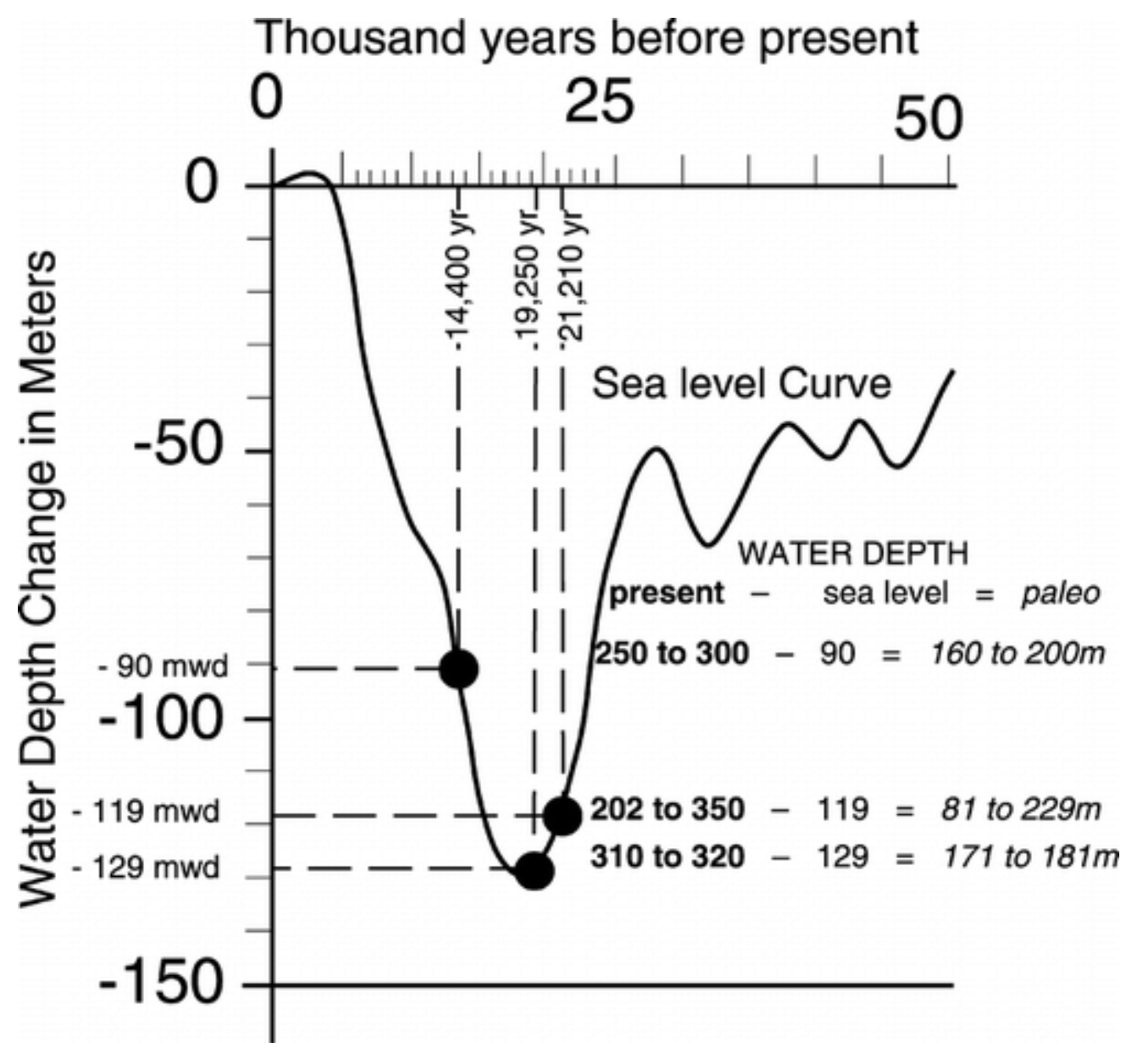

FIGURE 8-Curves used to estimate water depth at the shelf margin during the late Pleistocene. Sea level curve derived from Oxygen isotope data (after Chappell and Shackleton, 1986). Carbon $^{-14}$ dates of relict bioclasts (James et al., 1997) 14,400 ybp, 19,250 ybp, and 21,210 ybp correspond to drops in sea level of $90 \mathrm{~m}, 119, \mathrm{~m}$ and $129 \mathrm{~m}$, respectively. Thus, late Pleistocene relict bioclasts collected from modern water depths of 200-350 m would have lived in water depths corresponding to 81-229 m water depth 


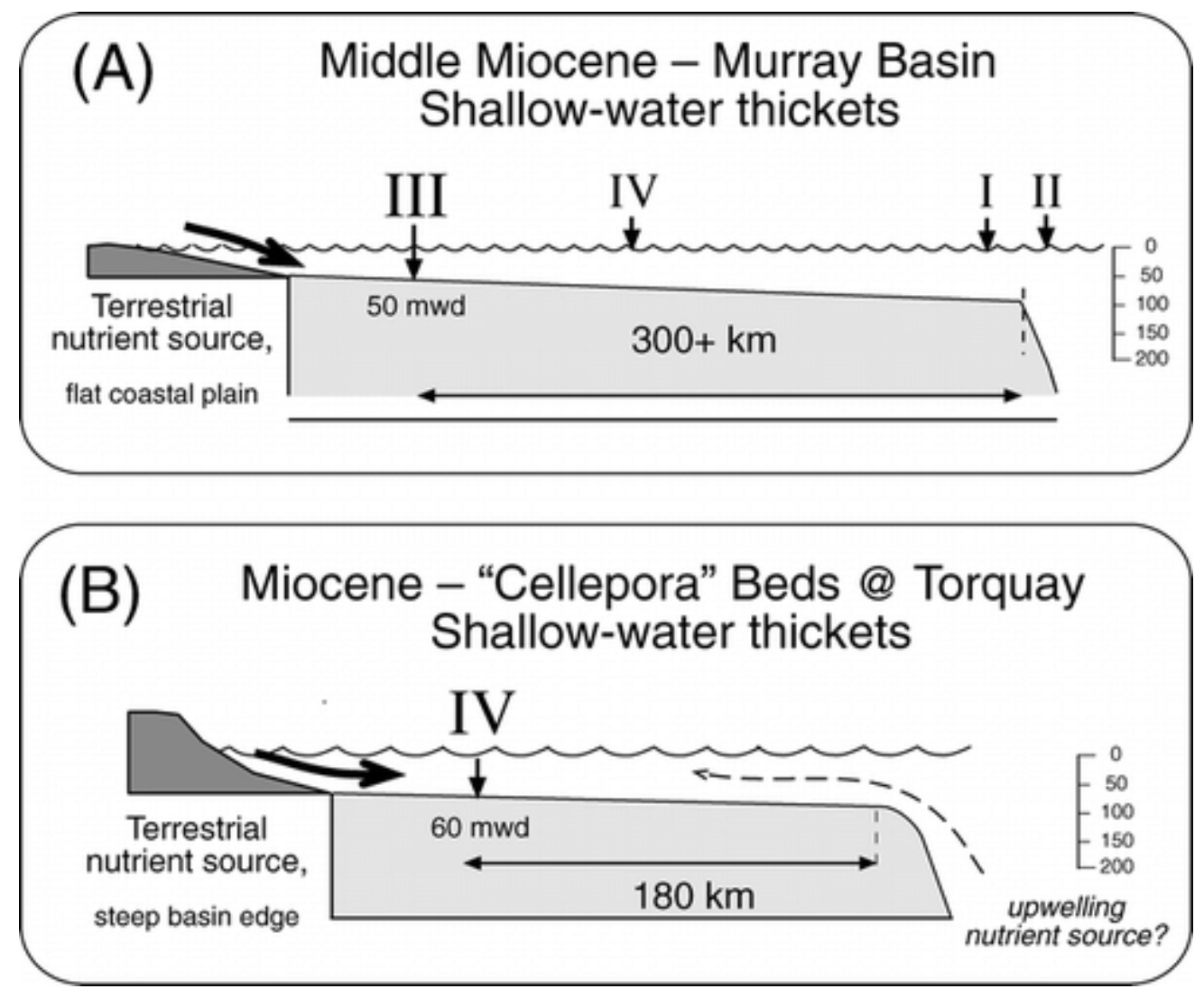

FIGURE 9-Generalized reconstructions (at different scales) of the Miocene southern Australian margin (continent to left, Southern Ocean to right). Labels I-IV correspond to the relative geographic location of Celleporaria thickets denoted by labeled asterisks on Fig. 1. Arrows propose the source of nutrients in each setting. (A) Profile of Middle Miocene Murray Basin, South Australia. (B) Early Miocene of Torquay Basin, Victoria 

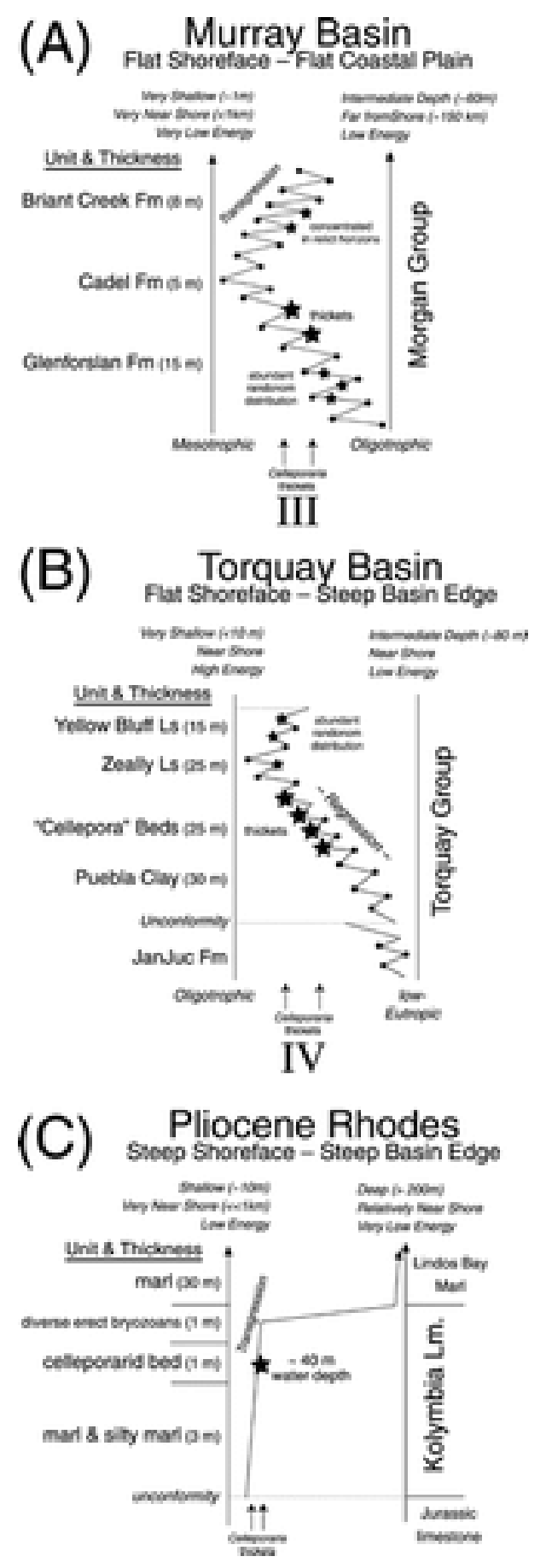

FIGURE 10- Generalized stratigraphy, relative sea level, and trophic resource curves. In all settings, Celleporaria thickets form at a transition to mesotrophic nutrient levels in sub-wavebase conditions. Roman numerals III-IV refer to geographic positions on Figs. 1, 7, 9 and 11. (A) Ledge-forming cycles of Celleporaria in the upper Glensforlan Limestone of the Middle Miocene, Morgan Group from the Murray Basin, South Australia (after Lukasik et al., 2000). (B) Type section for the Early Miocene Puebla Formation, of the Torquay Basin, Victoria. (C) Section of Late Pliocene Kolymbia Limestone, island of Rhodes, Greece (after Spjeldnaes and Moissette, 1997) 


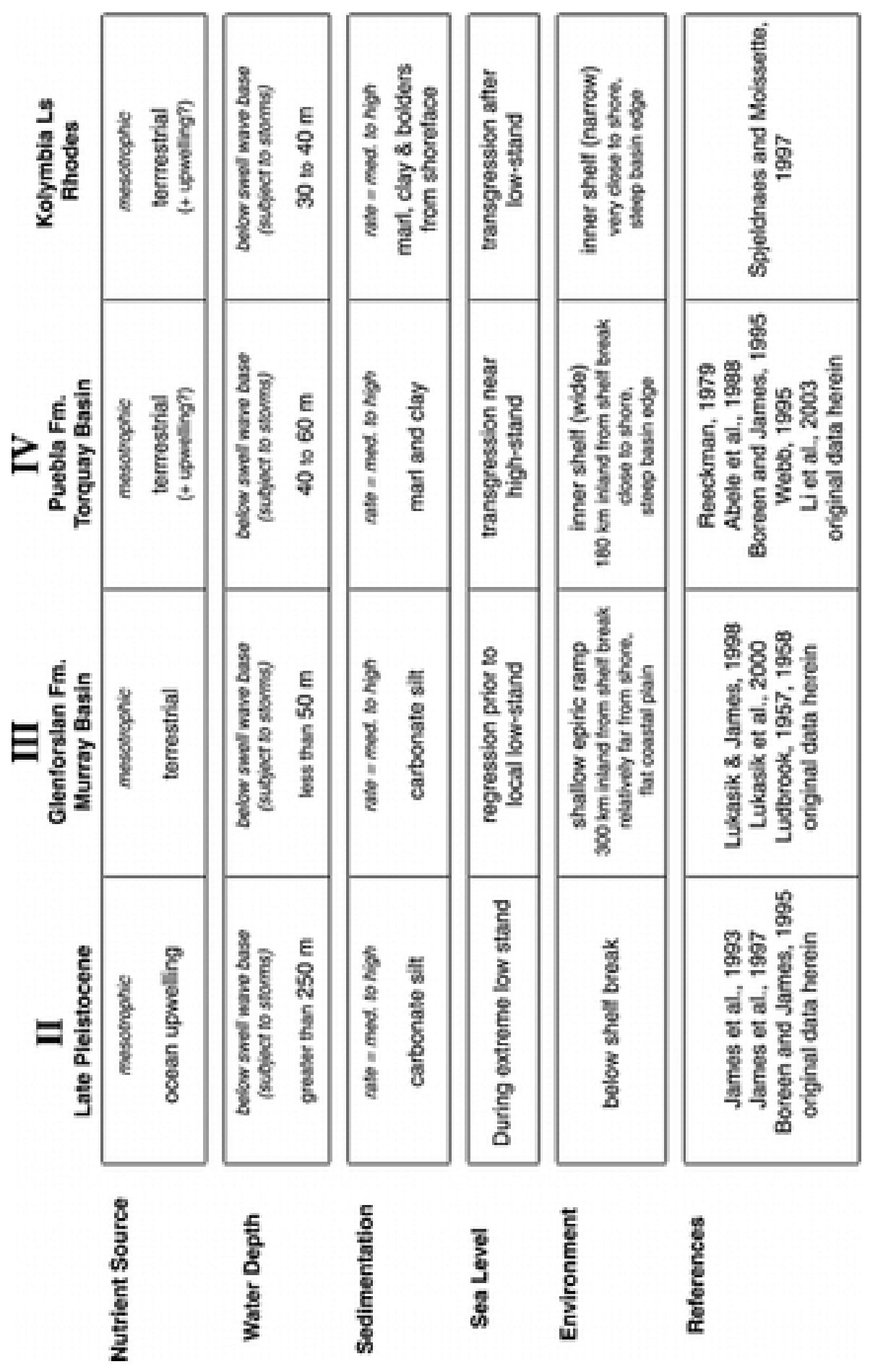

FIGURE 11-Comparison of environmental parameters for one deep and three shallow Celleporaria thickets. Roman numerals II-IV refer to geographic positions on Figs. 1, 7, 9, and 10 


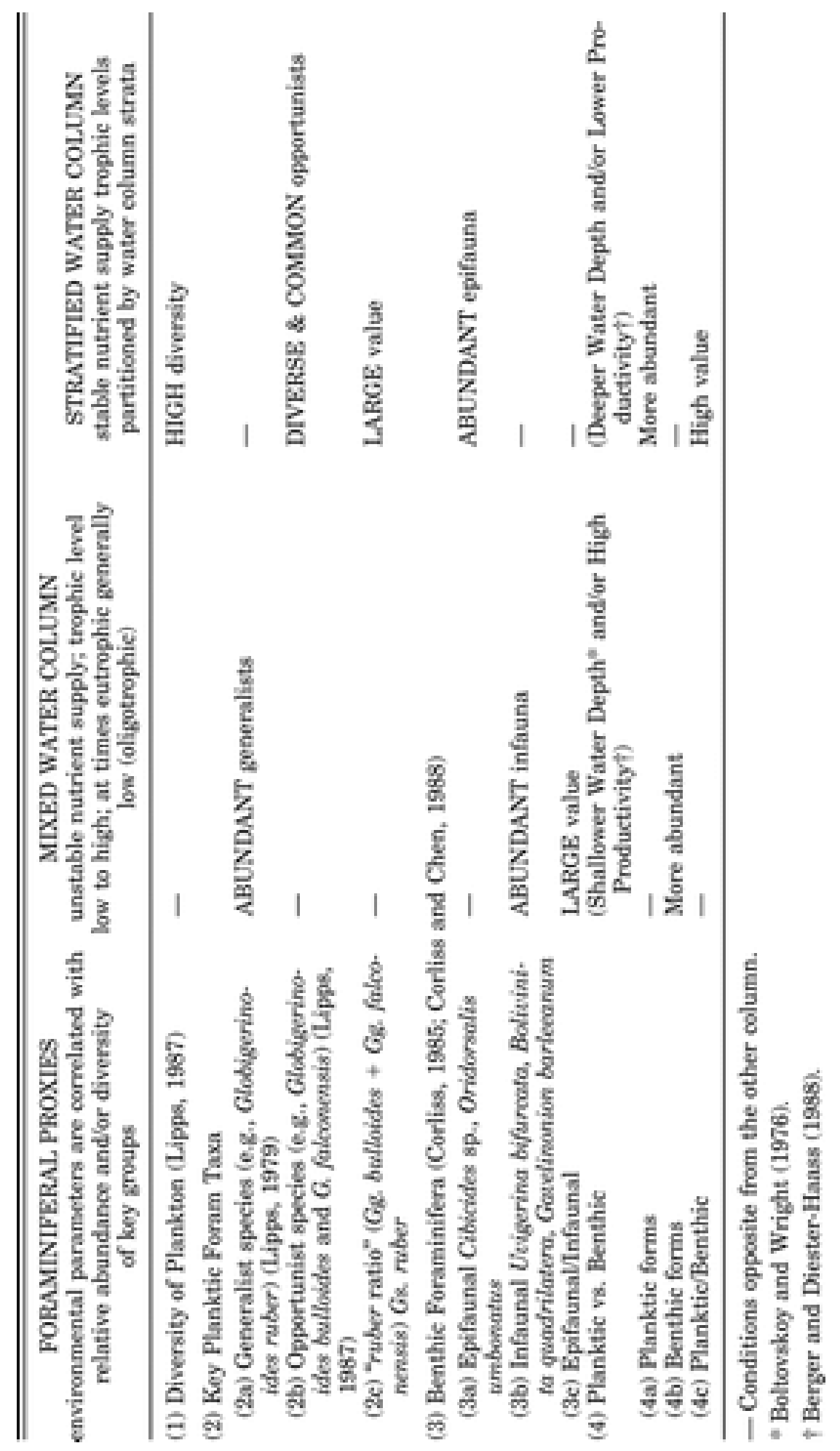

TABLE 1-Neritic ecological conditions characterized by the diversity and abundance of key foraminiferal taxa 


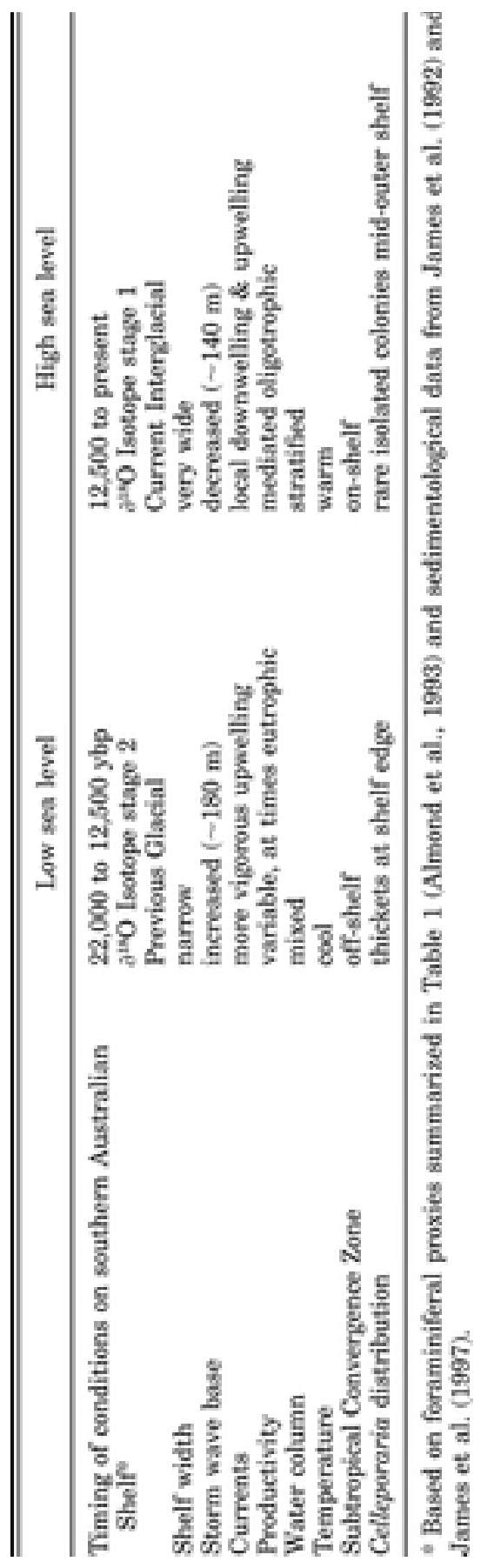

TABLE 2-Summary of physical conditions on the southern Australian shelf margin during times of high and low sea level (after Caron and Holmwood, 1983 and Almond et al., 1993). Shelf edge Celleporaria thickets flourished during times low sea level stands among upwelling of cool nutrient-rich, mixed waters* 